\title{
The research station "Vaskiny Dachi", Central Yamal, West Siberia, Russia - A review of 25 years of permafrost studies
}

\author{
MARINA LEIBMAN, ARTEM KHOMUTOV, ANATOLY GUBARKOV, DAMIR MULLANUROV AND \\ YURY DVORNIKOV
}

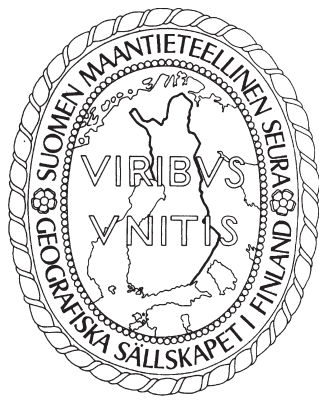

Leibman, Marina, Artem Khomutov, Anatoly Gubarkov, Damir Mullanurov \& Yury Dvornikov (2015). The research station "Vaskiny Dachi", Central Yamal, West Siberia, Russia - A review of 25 years of permafrost studies. Fennia 193: 1, pp. 3-30. ISSN 1798-5617.

The research station "Vaskiny Dachi" on the Yamal Peninsula was established in 1988. Activities were aimed at monitoring of permafrost and related environmental features under a relatively low level of nature disturbances caused by gas field development. Cryogenic processes that may affect the environment and the structures have been of primary interest. Landslides are the most common cryogenic processes in Central Yamal in general and also in the proximity of the station. Field surveys of numerous landslides, analysis of their dependence on climatic parameters and their fluctuations resulted in novel classification of cryogenic landslides based on mechanisms of their development. Dating by radiocarbon and dendrochronology allows the separation of cycles of landslide activation. Cryogenic landslides control the development of other processes, such as thermal erosion, river channel erosion and thermokarst. It also affects topography, vegetation pattern, geochemistry of vegetation, ground water and soils. As a result, permafrost parameters, specifically active layer depth and ground temperature, moisture and ice content in the active layer, depend indirectly on landsliding. Monitoring within the framework of the main programs of the International Permafrost Association, such as Circumarctic Active Layer Monitoring (CALM, since 1993) and Thermal State of Permafrost (TSP, since 2011), play an important role among the research activities. From the collected data one can conclude that ground temperature increased on average by about $1^{\circ} \mathrm{C}$ since the 1990s. At the same time, active layer fluctuations do not exactly follow the air temperature changes. Spatial changes in ground temperature are controlled by the redistribution of snow which is resulting from strong winds characteristic for tundra environments and the highly dissected relief of Central Yamal. Temporal variations rather depend on air temperature fluctuations but the rate differs in various landscape (environmental) units. While the spatial distribution of active layer depth depends on lithology and surface covers, temporal fluctuations are controlled by ground temperature, summer air temperature, summer precipitation, and in general may contravene climate warming due to specific combination of all factors.

Keywords: Yamal Peninsula, permafrost, field survey and monitoring, active layer, ground temperature, cryogenic processes

Marina Leibman, Earth Cryosphere Institute, Russian Academy of Sciences, Siberian Branch, Malygin street 86, Tyumen 625000, Russia \& Tyumen State Oil and Gas University, Volodarsky street 38, Tyumen 625000, Russia, E-mail: moleibman@mail.ru

Artem Khomutov, Damir Mullanurov \& Yury Dvornikov, Earth Cryosphere Institute, Russian Academy of Sciences, Siberian Branch, Malygin street 86, Tyumen 625000, Russia, E-mails: akhomutov@gmail.com, damir.swat@mail.ru, ydvornikow@gmail.com

Anatoly Gubarkov, Tyumen State Oil and Gas University, Volodarsky street 38, Tyumen 625000, Russia, E-mail: agubarkov@gmail.com 


\section{Introduction}

The Vaskiny Dachi research station $\left(70^{\circ} 20^{\prime} \mathrm{N}\right.$, $68^{\circ} 51^{\prime} \mathrm{E}$ ) (Fig. 1) was established in 1988 as a component of scientific support for railroad construction and carbohydrates exploration on the Yamal Peninsula. It is located within a region of continuous permafrost. Tundra lakes and river flood plains are the most prominent landscape features. Within over 25 years of continuous monitoring, a unique database is established as well as bench marking research in periglacial geomorphology is undertaken. Observations from recent years confirmed previously developed concepts, specifically the activation of cryogenic landslides in the form of earth flows has been proven to extend over territory with massive ground ice due to warmer summers.

This review paper summarizes the historical development and scientific achievements. Findings have been to date mostly published in Russian language. The aim of this paper is to present this research concisely and to demonstrate the value of detailed long-term ground measurements for validating remote-sensing products.

\section{Historical review}

The spatial limits of the study area were chosen depending on the availability of aerial photographic data obtained in 1990 covering about $90 \mathrm{~km}^{2}$. Several sites to study cryogenic processes were established and a tachometric survey carried out during the first years. This was complemented by landscape and landslide mapping starting 1989. Since 1993, after a Circumarctic Active Layer Monitoring (CALM) site was established at VD, the station was included into the CALM Program under the ID 'R5' (http://www.gwu.edu/ calm/data/north.html). Data are published as a part of the GTN-P database (http://gtnpdatabase.org/activelayers/view/114\#. U8Upj7HBaSk). In 1995, a "Landslide cirque" supersite was selected and studied in detail. A topographic survey, soil sampling, dendrochronology, radiocarbon dating, biomass, and biogeochemical sampling were performed within this site. In 2010, the boreholes of early 1990s were re-drilled and VD joined the Thermal State of Permafrost (TSP) Program. In 2007, VD became a part of the North Eurasian Transect within the Land Cover Land Use Change for Yamal Peninsula (LCLUC-Yamal) pro-
Fig. 1. The location of Vaskiny Dachi research station: West Siberia with Yamal peninsula (http:// www.freeworldmaps.net/ russia/russia-map.jpg) (a); Yamal peninsula with the location of Vaskiny Dachi (b); and GeoEye-1 satellite image (Copyright GeoEye, Inc) showing Vaskiny Dachi research station (c). a

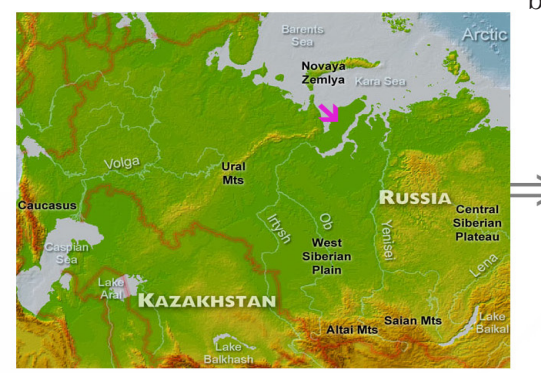

b

C

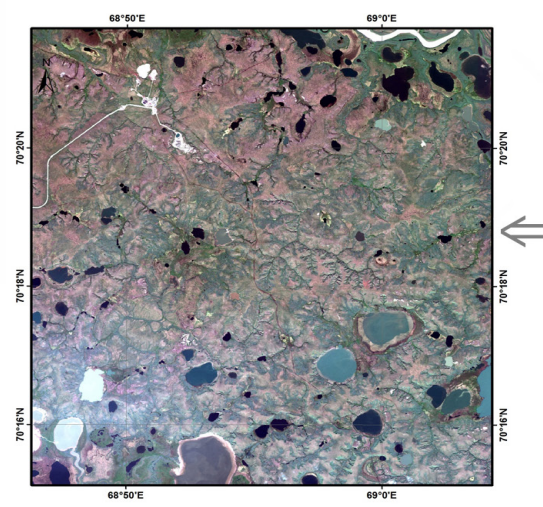

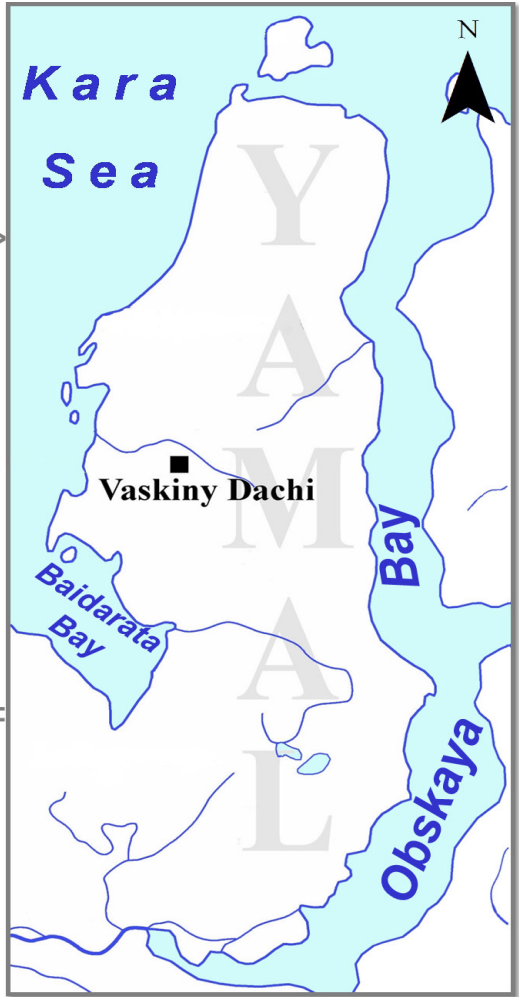


ject with 3 more LCLUC-CALM grids and shallow boreholes established (http://www.geobotany.uaf. edu/yamal/, Leibman et al. 2012). In 2011, a 1.5 $\mathrm{km}$ long transect was established, and tachometry, geobotany and active layer lithology and depth were surveyed. CALM sites, TSP boreholes and Transect were continuously used as permafrostvegetation monitoring objects since then (Fig. 2).

Cryogenic landslides have been of primary concern since 1989, after extensive slope process activation. This was followed by an intensive period of active layer and ground temperature monitoring, starting in 1993, what became one of the main research topics until today. In 2011, thermokarst lakes were included in the complex of field studies: the bathymetry of several lakes was done as well as water sampling for optical properties. Current research includes the parameterization of ground cover for the permafrost temperature modeling, and the usage of remotely sensed data.

International scientists from the USA, Finland, and Germany participated in joint field work. Geocryologists, cryosol scientists, geobotanists, geoecologists, engineering geologists and other specialists from several Russian Research Institutes and Universities took part in the field work as well. During 25 years of VD activity numerous diploma works, six Candidate of Sciences and one Doctor of Science theses fully or partly based on VD data were defended. More than 50 undergraduate and graduate students were trained at this station. About 70 papers, two monographs, and six book chapters were published using VD data.

\section{Physiography, climate and permafrost of Central Yamal within the Mordy- Yakha-Se-Yakha watershed}

Vaskiny Dachi research station is located at the watershed of Se-Yakha and Mordy-Ykha rivers covering a system of highly-dissected alluvial-lacustrine-marine plains and terraces where a number of hazardous processes operate, such as thermal erosion and landsliding. The deposits are sandy to clayey, most are saline within permafrost, and some are saline in the active layer. The periphery of hilltops is embraced by windblown sand hollows, covering large areas. Saddles between the hilltops are often covered by polygonal peatlands bearing ice wedges, while some convex hill tops are occupied by wellshaped sandy polygons with sand-and-ice wedges.
Slopes comprise a mosaic of concave and convex surfaces, first being ancient and modern landslide shear surfaces, and second being stable slopes.

Maximum heights (up to $58 \mathrm{~m}$ ) are linked to the tops of the Salekhardskaya $\left(\mathrm{V}^{\text {th }}\right)$ marine plain. The depth of dissection at this level is $20-50 \mathrm{~m}$. The geological section is built of saline clay with clastic inclusions of marine and glacio-marine origin. The surficial layer which is several centimeters to several decimeters thick is washed out and is represented by non-saline silty sand enriched with clasts through wind erosion. The Kazantsevskaya (IVth) coastal-marine plain is $40-45 \mathrm{~m}$ high, built of interbedding of saline clayey and sandy deposits with essential amount of organic matter dispersed in the section. The surface is sometimes covered by washed out windblown sands, but mainly with tussocky, hummocky or spot-medallion tundras and peatlands at the concavities. The Third (IIIrd) alluvial-marine or alluvial-lacustrine terrace is up to $26 \mathrm{~m}$ high, built of fine interbedding of sandy, silty, loamy, and organic layers of several millimeters to several centimeters thick. Flat hilltops are often occupied by polygonal sandy landscapes with windblown sand hollows on the tops of highcentered polygons. Lowered surfaces are hummocky tundras. Lower terraces are of fluvial origin, including the flood plains of Mordy-Yakha and SeYakha rivers and their smaller tributaries: NgermLymbadyakha, Panzananayakha, Khalmeryakha. Up to $60 \%$ of the study area is represented by gentle slopes (less than $7^{\circ}$ ), slopes $7-50^{\circ}$ steep occupy about $10 \%$ of the area, the remaining $30 \%$ being hilltops, river-valley and lake-depression bottoms.

Mean annual air temperature according to the weather station Marre-Sale in 2004-2013 ranges at -4.1 to $-8.3{ }^{\circ} \mathrm{C}$, average for the last 10 years is $-6.4{ }^{\circ} \mathrm{C}$ (Table 1). The ten-year trend is $0.6{ }^{\circ} \mathrm{C}$. The annual atmospheric precipitation is $260-400 \mathrm{~mm}$. About half falls as snow (8-8.5 months), and half as rain (3.5-4 months). The snow thickness on the flat surfaces is up to $30 \mathrm{~cm}$, while on the leeward slopes and in the valleys it may reach several meters (our observations in late spring indicated $6 \mathrm{~m}$ ).

The study area is characterized by continuous permafrost. Open taliks are possible only under the bigger lakes with 30-50 m depth. Smaller lakes which are only several $\mathrm{m}$ deep have closed taliks (5-7 $\mathrm{m}$ thick) under the lake bottom.

Permafrost thickness reaches $500 \mathrm{~m}$ and more on the marine and coastal-marine plains and reduces to 100-150 $\mathrm{m}$ at the younger river terraces (Yershov 1998). 


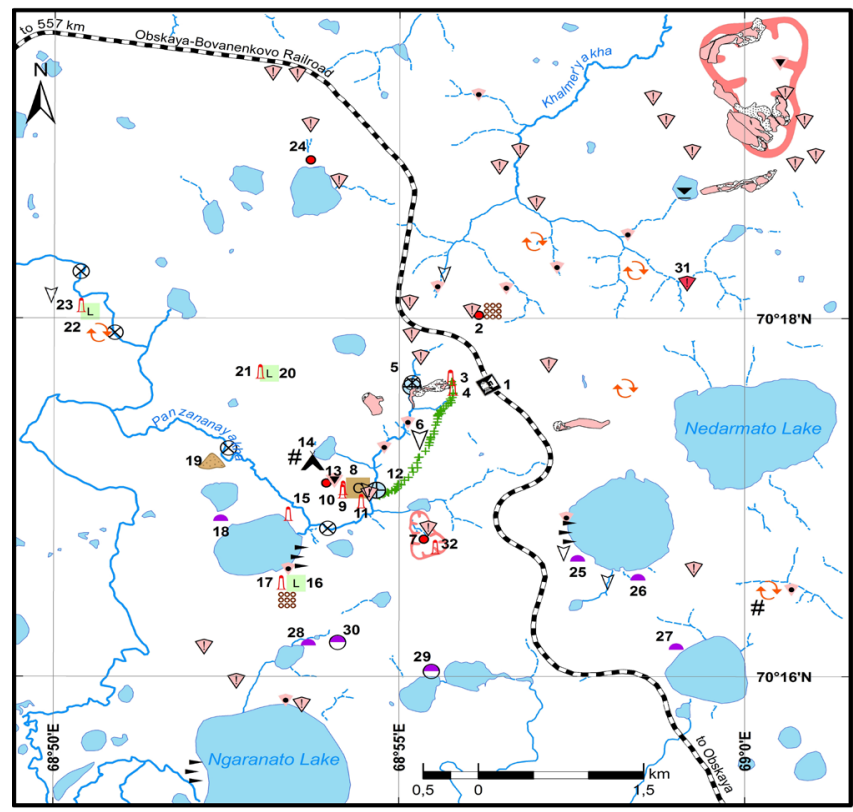

CRYOGENIC PROCESSES

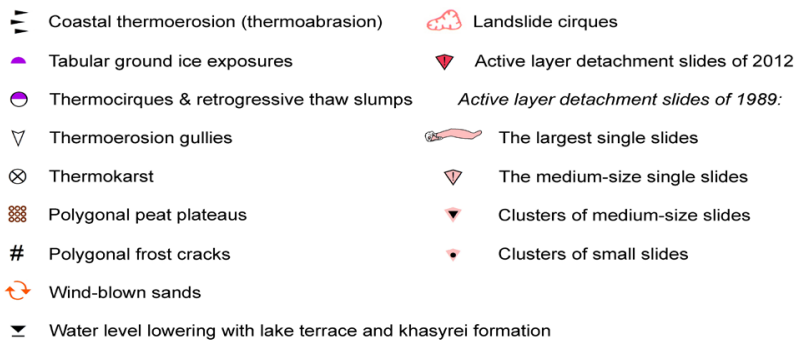

STATIONARY OBJECTS
$\triangle$ Boreholes
Monitoring grids:
- Points of detailed landslide studies
C CALM grid $100 \times 100 \mathrm{~m}$ (1993)
+ Points on experimental Transect
L LCLUC-CALM grids $50 \times 50 \mathrm{~m}$ (2007)

Fig. 2. Map of Vaskiny Dachi monitoring and survey objects. Test sites and landmarks: 1. Station "547 km" of ObskayaBovanenkovo Railroad (closed in 2013); 2. A test landslide cirque for geobotanical, soil, and dendrochronological study on ancient and young landslides; 3. A 1-m TSP borehole AGG1, drilled in 2011; 4. A 0.8-m TSP borehole AGG2, drilled in 2011; 5. Dammed lake formed by active layer detachment slide of 1989; 6 . Three-headed thermoerosion gully; 7 . A test landslide cirque for geobotanical, soil, radiocarbon, and dendrochronological study on ancient, old and young landslides; 8. CALM grid (R5 at http://www.udel.edu/Geography/calm/); 9. A 10-m TSP-CALM borehole, drilled in 2011; 10. A 1.5-m TSP-CALM borehole, active discontinuously since 1995, last re-drilled and equipped in 2005; 11 . A 1.5-m TSP-CALM borehole AG19/3, drilled and equipped in 2007; 12. Dammed lake formed by active layer detachment slide of 1989, drained in 2000; 13. A 1989 landslide for geochemical (redistribution of salts in the active layer) and geobotanical (re-vegetation of the shear surface) study; 14. Location of annual ECI expedition camp (former station ruined by vandalism); 15 . A 7-m TSP borehole, drilled as 30-m borehole in 80s, restored in 1993 to the depth $10 \mathrm{~m}$, and re-drilled and equipped to the depth of $7 \mathrm{~m}$ in 2010; 16. LCLUC-CALM active layer monitoring grid VD-1, 50x50m; 17. A 0.9-m CALM-TSP borehole VD-1, drilled in 2007; 18. Tabular ground ice exposure in small thermocirque, first noted in 2005; 19. Abandoned re-vegetating sand quarry; 20. LCLUC-CALM active layer monitoring grid VD-2, 50x50m; 21. A 1-m CALM-TSP borehole VD-2, drilled in 2007; 22. LCLUC-CALM active layer monitoring 50 m transects VD-3; 23. A 1-m CALM-TSP borehole VD-3, drilled in 2007; 24. A landslide cirque of geobotanical and dendrochronological study on ancient and young landslides; 25. Tabular ground ice exposure, 2005-2008; 26. Tabular ground ice exposure, 2007-2008; 27. Tabular ground ice exposure first noted in 1988; 28. Tabular ground ice exposure first noted in 1989, exhausted in 2000; 29. Thermocirque of 2012; 30. Cryogenic earth flow of 2012; 31. Translational cryogenic landslide of 2012; and 32. Borehole in test landslide cirque drilled in 2013. 
Average annual ground temperature at the depths of zero annual amplitude ranged between 0 and $-7^{\circ} \mathrm{C}$ during the last decade (up to $-9{ }^{\circ} \mathrm{C}$ in 1980s). The lowest temperature is characteristic for the hilltops with sparse vegetation where snow is blown away. The warmest are areas with high willow shrubs due to the retention of snow, on slopes and in the valleys and lake depressions.

Active layer depth (ALD) ranges between 40 $\mathrm{cm}$ under the thick moss up to $120 \mathrm{~cm}$ on sandy, poorly vegetated surfaces (Melnikov et al. 2004; Vasiliev et al. 2008; Leibman et al. 2010, 2011, 2012). There are extremes observed on highcenter sandy polygons, which can be 1-1.5 m high and up to $10 \mathrm{~m}$ in diameter, with active layer exceeding $2 \mathrm{~m}$. The measurements of thaw depth exceeding $1.5 \mathrm{~m}$ are obtained by probing in saline clay, which is exposed at the landslide shear surfaces. With the zero temperature at the depth of $80-90 \mathrm{~cm}$, it contains no ice to over $1.5 \mathrm{~m}$ depth (ground temperature about $-1{ }^{\circ} \mathrm{C}$ ) (Leibman 1997, 2001).

Cryogenic processes observed in the area are connected to tabular ground ice found in geological sections at the depths of 1 to $25 \mathrm{~m}$ prac- tically everywhere. The most widespread processes observed in the study area are the formation of landslides of various types (Leibman \& Egorov 1996), and thermoerosion (Sidorchuk 1999, 2000; Gubarkov 2009) due to the prevailing slopes. Aeolian processes are observed on convex hilltops. Less often observed are modern thermokarst and frost heave. Cryogenic landslides (active layer detachments) were the most active in August 1989. About 400 new landslides in the area of $90 \mathrm{~km}^{2}$ appeared, while previously only 3 modern landslides and hundreds of ancient landslides were known.

Due to warm summers, several new exposures of tabular ground ice were formed by landslide activity in recent years (years 2005, 2007, 2011 and 2012 in Table 1). In 20112012, several new, large thermocirques appeared at the lake margins. Where tabular ground ice is observed in the bottom of thermocirques, a start of thermokarst may be initiated in these landforms.

In 1986-1993, the investigations for railway construction were very active, so tundra was disturbed by vehicle tracks which gave start to lateral thermoerosion. After 1993 due to the

Table 1. Climatic parameters at the nearest weather station Marre-Sale, about $100 \mathrm{~km}$ to the west-southwest of Vaskiny Dachi (minimums in blue, maximums in red, bold).

\begin{tabular}{|c|c|c|c|c|c|c|c|}
\hline 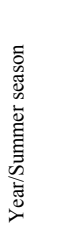 & 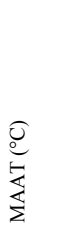 & 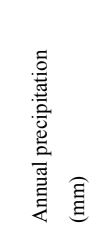 & 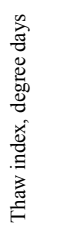 & 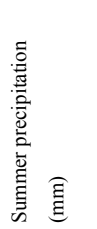 & 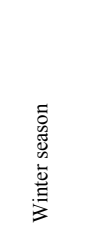 & 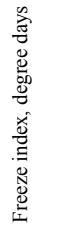 & 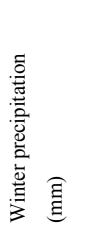 \\
\hline 2004 & -7.7 & & 807 & No data & & & \\
\hline 2005 & -5.4 & & 879 & 276 & 2004-2005 & -2710 & No data \\
\hline 2006 & -8.0 & 401 & 710 & 206 & 2005-2006 & -3181 & 195 \\
\hline 2007 & -5.0 & 266 & 904 & 126 & 2006-2007 & -3049 & 139 \\
\hline 2008 & -5.0 & 380 & 764 & 181 & $2007-2008$ & -2748 & 200 \\
\hline 2009 & -8.3 & No data & 807 & 161 & 2008-2009 & -2974 & No data \\
\hline 2010 & -8.1 & 371 & 468 & 221 & 2009-2010 & -3785 & 150 \\
\hline 2011 & -4.4 & 360 & 755 & 111 & 2010-2011 & -2788 & 249 \\
\hline 2012 & -4.1 & No data & 999 & No data & 2011-2012 & -2271 & No data \\
\hline 2013 & -8.2 & No data & 744 & No data & 2012-2013 & -3105 & No data \\
\hline Mean & -6.4 & - & 784 & - & Mean & -2956 & - \\
\hline
\end{tabular}


cessation of the railway project, most tracks got re-vegetated and thermoerosional troughs got flattened and filled in by sediment. Yet natural thermoerosion developing on the shear surfaces of landslides is active since landsliding started.

A striking aspect of the vegetation of the central Yamal region is the abundance of willow thickets (Salix lanata and S. glauca) that cover many hill slopes and valley bottoms. The desalination of old marine sediments after numerous landslide events lead to active layer enrichment with water-soluble salts, which supply plants with nutrition, provide active re-vegetation by herbs, and reformation of soils, followed by willow shrubs' expansion. This expansion is supported by snow accumulation in the concavities produced by landslides. Willow shrubs provide more nutrition than typical tundra vegetation like moss-lichen-grass communities, due to the leaf litter (Ukraintseva et al. 2000, 2003, 2014; Ukraintseva \& Leibman 2007).

\section{Active-layer and ground temperature studies}

Ongoing research at the Vaskiny Dachi research station includes: active layer and ground temperature monitoring; surveys (topographic, landscape, geobotanic, of cryogenic processes, of snow cover); mapping (DEM, GIS, cryogenic processes and landforms on slopes, in the river valleys, at the lake shores, lake bathymetry); drilling and digging for soil properties and biogeochemical sampling; and studying the mechanisms and interrelations of cryogenic processes.
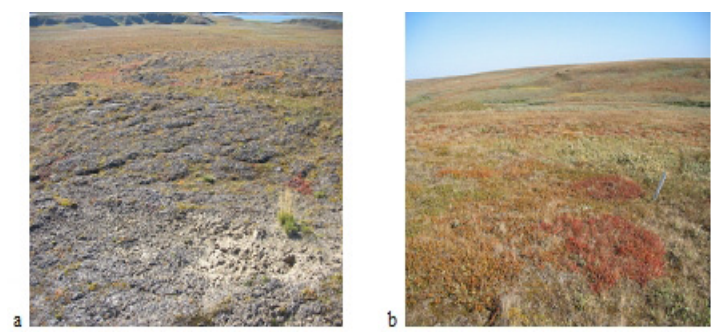

Fig. 3. Characteristic landscapes of the VD CALM grid: poorly vegetated hilltop (a) and densely vegetated, shrubby mossy slope (b). (Photos by Khomutov and Leibman).

\section{Active layer monitoring and mapping}

Active-layer depth is measured by a metal probe according to CALM protocol within 4 grids and along the Transect. Such a grid is fundamental for the study of spatial and temporal variations. These include lithological and cryogenic controls and surface cover controls for spatial distribution. Temporal variations are controlled by climate fluctuations which are mediated by topography, lithology and surface covers (Leibman 1998).

The VD CALM grid has been active since 1993. It was placed on the top and slope of a highly dissected alluvial-lacustrine-marine plain, affected by landslides, with sandy to clayey soils (Fig. 3). Monitoring has shown that the main controls of the active-layer dynamics are types of surficial deposits, moisture content in the fall, the thickness of organic cover, and air temperature in summer. In general, maximum ALD (1-1.2 m) is found in sands on bare surfaces or with sparse vegetation and low moisture content (up to $20 \%$ ). Minimum ALD $(50-60 \mathrm{~cm})$ is found in peat or clay deposits covered by thick moss and with moisture contents more than $40 \%$ (Fig. 4).

During the Yamal-LCLUC NASA project field work in 2007 vegetation indices were measured at the grids. These measurements allowed to investigate the relations between ALD, Normalized Difference Vegetation Index (NDVI), as well as Leaf Area Index (LAI), measured with field spectrometers (Khomutov et al. 2010; Leibman et al. 2008, Fig. 5). In general, for the entire CALM grid, the higher the vegetation indices and parameters the lower the ALD. This agrees with the generally accepted effect of vegetation insulation on ground temperatures and ALD (Osadchaya 1987; Melnikov et al. 2004).

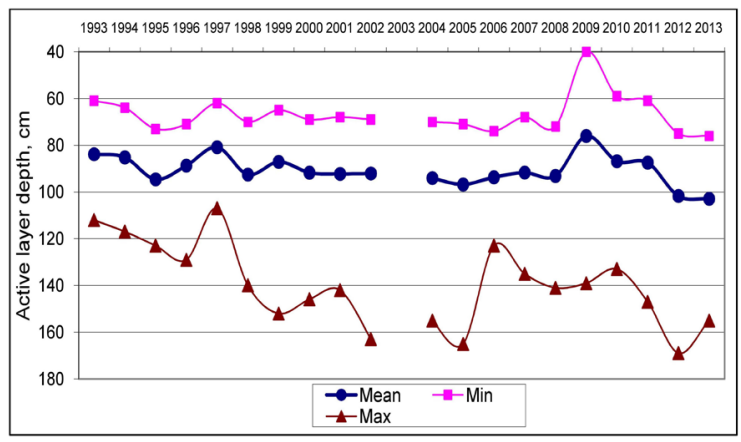

Fig. 4. Summary of active layer depth measurements (min, max and average of 121 grid nodes) at the CALM grid since 1993. 


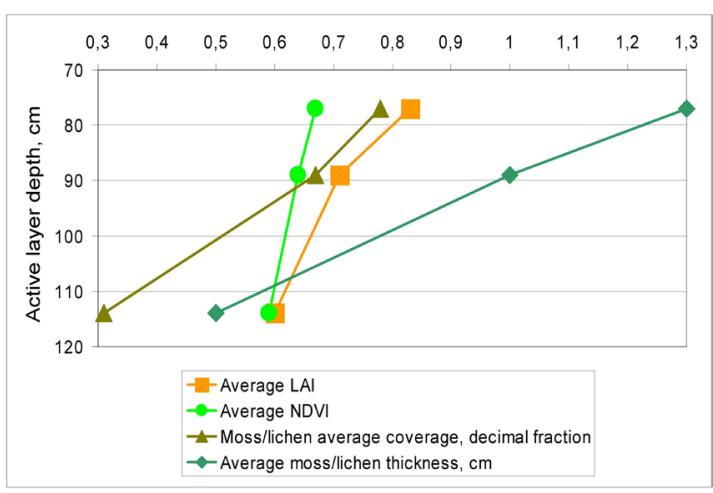

Fig. 5. The relation between the ALD and vegetation indices NDVI and LAI at the CALM grid.

The increase of active layer depth in 2012 compared to previous years is related to extremely warm spring. The warm period started on May 25; maximal average daily temperature was $+18.0^{\circ} \mathrm{C}$ on June 29, and the thaw index calculated for the period from May 25 to September 2 (the date of the ALD measurement) was 854 degree days with an amount of precipitation of $257 \mathrm{~mm}$. To compare, the same values for the period from May 12 to September 4 of the previous warmest year of 2005 were 661 degree days and $146 \mathrm{~mm}$, respectively. In 2013, active layer depth measured by metal probe on the CALM grid averaged at $103 \mathrm{~cm}$ in a range of 76 to $155 \mathrm{~cm}$. This is $15 \%$ higher than perennial average $(89 \mathrm{~cm})$ and $6 \%$ higher than maximal average $(2005,97 \mathrm{~cm})$ in the period of 1993-2011.

Climatic parameters in 2013 (thaw index 656 degree days and the amount of precipitation $114 \mathrm{~mm}$ from June 8 to September 2, and freeze index -3105 degree days for 2012-2013 winter) have been much lower than in 2012, so they are likely not the most important factors in maintaining the abnormally high ALD during that summer. We suggest that abnormally deep thaw in 2013 is due to the delayed refreezing in the fall 2012. Thus, while the spatial distribution of the ALD is controlled by the lithology of the active layer and surface covers, temporal fluctuations are mainly under the impact of air/ground temperature and partly by precipitation.

ALD measurements on the CALM grid were related to (1) the vegetation indices (NDVI \& LAI), established in previous studies (Walker et al. 2003), and (2) the parameters of vegetation cover (the height and thickness of shrubs, herbs and moss). It can be argued that NDVI/LAI is usually less than 0.5/0.7 for convex well-drained poorly-vegetated surfaces, including windblown sands where ALDs exceed $100 \mathrm{~cm}$, vary from $0.5 / 0.7$ to $0.8 / 1.0$ for mesic, medium-vegetated surfaces with ALDs between 70 and $100 \mathrm{~cm}$, and over 0.8/1.0 for poorlydrained concave densely vegetated surfaces with ALDs typically less than $70 \mathrm{~cm}$ (Table 2).

The distribution of ALDs at the Vaskiny Dachi key site is shown in Figure 6 (Khomutov 2010, 2012; Khomutov \& Leibman 2010a; Khomutov \& Leibman 2011). Landscape complexes were grouped according to the identified ranges of vegetation indices and ALDs (Fig. 6). Fluvial forms (drainage hollows, ravines, small stream valleys) are included in the contour with ALDs more than $100 \mathrm{~cm}$ because they are subject to a stream warming effect.

\section{Ground temperature monitoring}

Boreholes at Vaskiny Dachi research station are equipped under the CALM and TSP Programs with HOBO data loggers. The depth of boreholes ranges from $1 \mathrm{~m}$ up to $10 \mathrm{~m}$. Ground temperature $(\mathrm{Tg})$ was first measured to the depth of $10 \mathrm{~m}$ in 1993 at VD in a borehole LGT, which was drilled in 1988. Then $\mathrm{Tg}$ at $10 \mathrm{~m}$ depth was $-6.5^{\circ} \mathrm{C}$. This borehole was cleaned again in 2010 to the depth of only 7 m (Fig. 7a). Mean annual Tg at 7-m depth is about $-5^{\circ} \mathrm{C}$.

Borehole 191-m was drilled next to the CALM grid in 1990 to the depth $10 \mathrm{~m}$ and Tg was measured by mercury thermometers in summer only till 1996. $\mathrm{Tg}$ range at a $10 \mathrm{~m}$ depth was -6.5 to $-6.8^{\circ} \mathrm{C}$. In 2011, the borehole was replicated (new ID: VD

Table 2. The range of active layer depth (ALD), Normalized Difference Vegetation Index (NDVI) and Leaf Area Index (LAI), measured with field spectrometers, for major categories of landscape.

\begin{tabular}{lccc}
\hline Surfaces & $\begin{array}{c}\text { ALDs } \\
(\mathrm{cm})\end{array}$ & NDVI & LAI \\
\hline Relatively drained poorly-vegetated and wind-blown sands & $>100$ & $<0.5$ & $<0.7$ \\
Poorly-drained medium-vegetated & $70-100$ & $0.5-0.8$ & $0.7-1.0$ \\
Wet concave densely vegetated & $<70$ & $>0.8$ & $>1.0$ \\
\hline
\end{tabular}




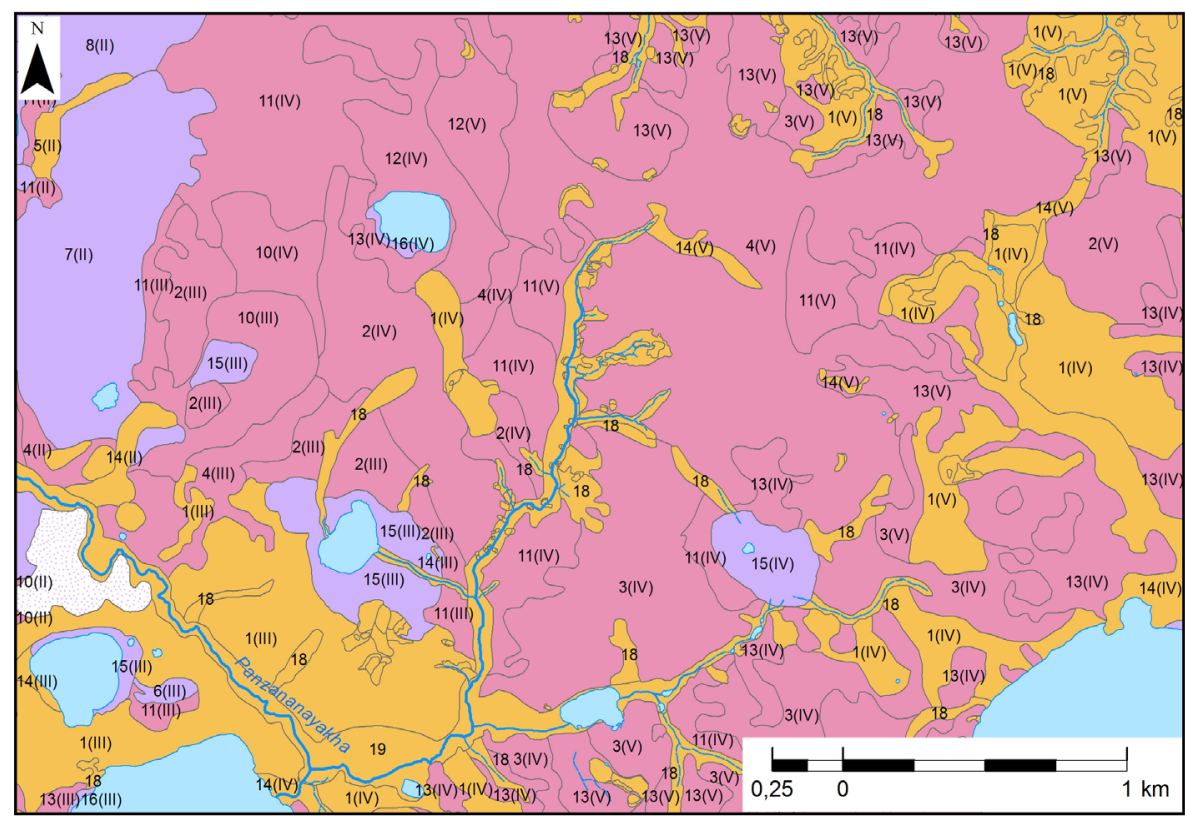

Active layer depths, $\mathrm{cm}$

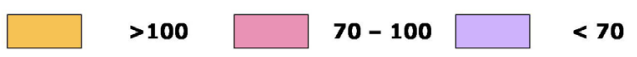

Fig. 6. Map of ALD range within subdivided landscape complexes (after A.V. Khomutov, fragment).

CALM_10) in the same place and equipped with $\mathrm{HOBO}$ data loggers. Mean annual Tg at $10 \mathrm{~m}$ depth during the last years is around $-6{ }^{\circ} \mathrm{C}$ (Fig. $7 \mathrm{~b}$ ).

Ground temperature measurements in the shallow boreholes were used to understand the process of freeze back in various landscape conditions (Table 3). One can see (Table 3 ) that probably a water horizon formed at the depth $50 \mathrm{~cm}$ in VD 2. At this depth freezing slows down: zero temperature was observed nearly for a month. Temperature decrease at a depth of $1 \mathrm{~m}$ started earlier than at 50 $\mathrm{cm}$ depth, hence the refreezing started synchronously from the bottom upward and surface downward. The same pattern is observed in borehole VD 3. Actually within $1 \mathrm{~m}$ the temperature reached zero through all the depths synchronously. The analysis of the weather station records allows us to conclude that prolonged fall with positive temperatures near zero provided enough time for equalization of $\mathrm{Tg}$ along the entire borehole.

Shallow boreholes at the CALM site are located on the sandy, practically bare surface (VD CALM), and on a concave old landslide slope with clayey surface deposits and willow thickets (AG19/3), both $150 \mathrm{~cm}$ deep, extending below the active layer base. Mean annual ground temperature at the AL base is the lowest in the VD CALM borehole $\left(-5.2{ }^{\circ} \mathrm{C}\right.$ in average), because it is located on a convex surface lacking vegetation cover in summer and snow in winter (Fig. 8). The shallow borehole (1.7 m deep, 'Gully'), which has been monitored in 2012-2013, showed temperature above zero at all depths. It appeared that in winter this location was filled with a snowpack more than $3 \mathrm{~m}$ thick (Fig. 9). During the period September 4, 2012, to July $1,2013,1.1$ and $0.6{ }^{\circ} \mathrm{C}$ at the depths 0 and $1.7 \mathrm{~m}$, respectively, have been measured. As follows from the diagram (Fig. 9), the ground temperature at the depth $1.7 \mathrm{~m}$ was around $-0.1{ }^{\circ} \mathrm{C}$ during the entire winter due to the snow coverage.

Seasonal thaw and freeze back dates depend on snow accumulation and vegetation complexes as well. One can see that thaw in borehole AG19/3 starts much later than in the VD-CALM borehole, which is connected to the snow accumulation, insulating the site near AG19/3. On the hilltop, the snow is blown away all winter, while in the shrubs of a concave slope it stays till July. Freeze back in 

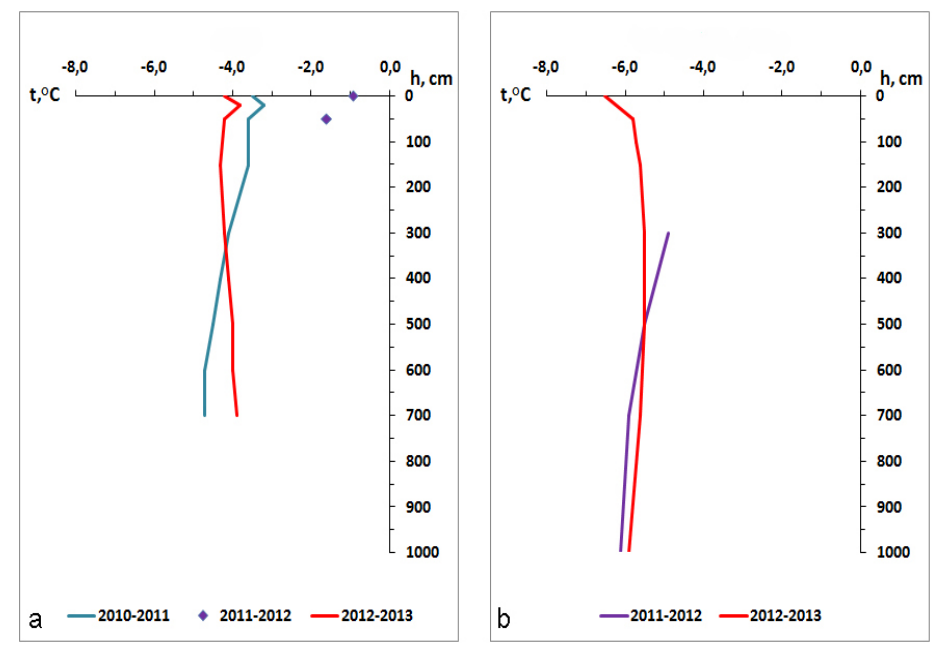

Fig. 7. Mean annual ground temperature in boreholes LGT (a) and 191 bis (b).

Table 3. The dates of the thaw and freeze back period in boreholes VD-1 (loam), VD-2 (sandy loam) and VD-3 (sand).

\begin{tabular}{|c|c|c|c|c|c|c|}
\hline Borehole & VD 1 & VD 2 & VD 3 & VD 1 & VD 2 & VD 3 \\
\hline Depth, cm & \multicolumn{3}{|c|}{ Spring thaw date } & \multicolumn{3}{|c|}{ Fall refreezing date } \\
\hline $0-6$ & 13.06 .08 & 11.06 .08 & 11.06 .0 & 30.09 .08 & 29.09 .08 & 28.09 .08 \\
\hline 25 & 24.06 .08 & 21.06 .08 & 27.06 .0 & 10.10 .08 & 01.10 .08 & 01.10 .08 \\
\hline 50 & - & 02.07 .08 & 12.07 .08 & - & $02.10 .-02.11 .08^{* *}$ & 02.10 .08 \\
\hline 100 & - & $16.09 .08^{*}$ & 06.08 .09 & - & $30.09 .08 * * *$ & 01.10 .08 \\
\hline
\end{tabular}

the shrubs also starts later on the bare surface due to the insulating action of the shrubs (Table 4).

Thus, snow accumulation in the shrub thickets on concave slopes is a much stronger control for $\mathrm{Tg}$ which increases to the values close to $0^{\circ} \mathrm{C}$.

\section{Cryogenic landslides}

In permafrost regions, the downslope movement of seasonally thawed ground has been widely reported. One of the most complete reviews covers the period up to 1964 (Kaplina 1965). A detailed study was undertaken in Russia after the widespread landslide event in the north of West Siberia, especially on Yamal Peninsula in 1989 (Ananieva 1984, 1997; Leibman et al. 1991, 1993a, 2000,
2003; Leibman 1994, 1995, 2004a, 2004b, 2005; Leibman \& Egorov 1996; Romanenko 1997; Poznanin \& Baranov 1999; Voskresensky 1999). Various aspects of this process were discussed: forcing factors and mechanisms, distribution and consequences (Leibman \& Egorov 1996). The latest monograph reviewing previous knowledge and suggesting classifications and mechanisms based on an extensive field study in the Kara sea region was published by Leibman and Kizyakov (2007). Specific aspects related to a strong impact of cryogenic landslides on all the components of geosystem, vegetation, soils, active layer, and ground temperature were analyzed and published in Russian (Leibman et al. 1993a, 1993b, 1997; Rebristaya et al. 1995; Leibman \& Streletskaya 1996, 1997; Ukraintseva et al. 2000, 2002, 2003; Strelet- 
skii et al. 2003; Ukraintseva \& Leibman 2007; Ermokhina 2009; Khomutov 2010, 2012).

\section{The mechanisms, landforms, distribution and classification of landslides}

The main topics of the landslide study at VD station were (1) the discovery, description and morphometric classification of all the landslides (Leibman 1995, 2005; Leibman \& Kizyakov 2007; Khomutov 2010); (2) mapping the landslide distribution at the study polygon about $90 \mathrm{~km}^{2}$ in size (Leibman 2005; Khomutov 2010, Fig. 10); (3) determining the age of landslides and cyclicity of their formation, the classification of landslides according to their age (Kizyakov \& Ermakov 2001;
Kizyakov 2005b; Leibman \& Kizyakov 2007); (4) suggesting mechanisms, forcing factors, triggers of landsliding, classifying landslides by mechanism (Leibman et al. 2000, 2003; Leibman 2004a; Leibman \& Kizyakov 2007), (5) understanding the consequences of landsliding found in the soils, vegetation, waters, topography and cryogenic processes of other mechanisms (Rebristaya et al. 1995; Leibman \& Streletskaya 1996, 1997; Ukraintseva et al. 2000, 2002, 2014; Leibman et al. 2003, 2014; Streletskii et al. 2003; Leibman \& Kizyakov 2007; Ukraintseva \& Leibman 2007), and finally (6) finding the ways of mapping and predicting landslides through the estimation of the landscape vulnerability to landslide activation (Khomutov 2010, 2012; Khomutov \& Leibman 2010a, 2010b, 2011).
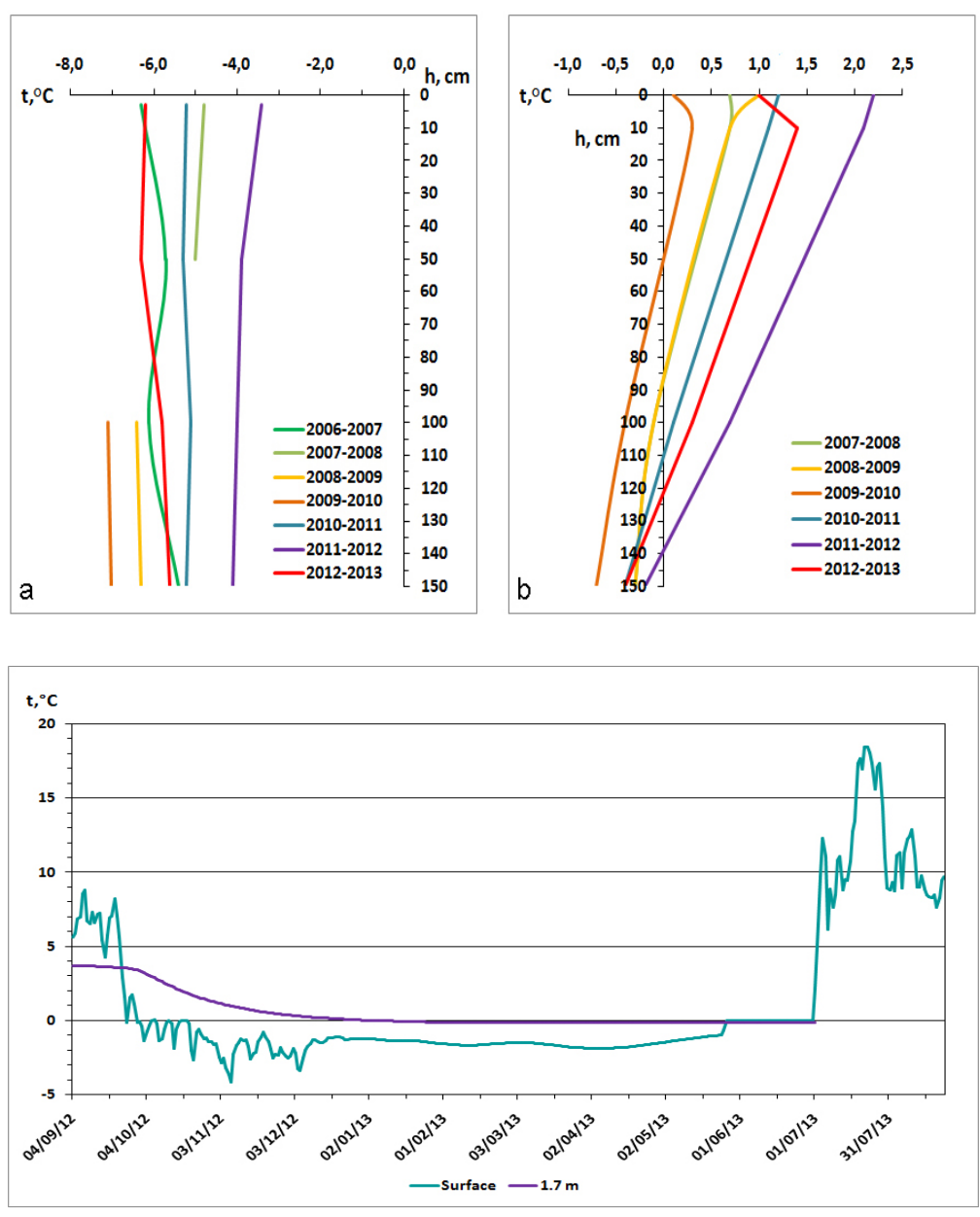

Fig. 8. Mean annual ground temperature in boreholes VD CALM (a) and AG19/3 (b).
Fig. 9. Ground temperature fluctuations on the ground surface and at the depth $1.7 \mathrm{~m}$ in borehole 'Gully'. 
Table 4. The dates of the thaw and freeze back period in boreholes VD-CALM (sandy-silty) and AG19/3 (clayey-loamy) in 2008.

\begin{tabular}{|c|c|c|c|c|}
\hline Borehole & VD CALM & AG19/3 & VD CALM & AG19/3 \\
\hline Depth, cm & \multicolumn{2}{|c|}{ Spring thaw dates } & \multicolumn{2}{|c|}{ Fall refreezing dates } \\
\hline $0-3$ & 11.06 .08 & 03.07 .08 & 28.09 .08 & 07.10 .08 \\
\hline 10 & 09.07 .08 & 04.07 .08 & 04.10 .08 & 09.10 .08 \\
\hline 100 & $30.07 .08^{*}$ & 06.08 .08 & $15.11 .08^{* *}$ & 05.10 .08 \\
\hline 150 & $24.08 .08 *$ & $30.09 .08 *$ & $24.11 .08^{* *}$ & $04.12 .08^{* *}$ \\
\hline
\end{tabular}

* The date of maximum negative temperature $-0.16^{\circ} \mathrm{C}$ at $100 \mathrm{~cm}$ and $1.06^{\circ} \mathrm{C}$ at $150 \mathrm{~cm}$

** The date of the start of upward freeze back

Different landscape types show a wide range of landslide impacts. Some landscape units may have more than $10 \%$ of the area disturbed by modern landslides (those which appeared in 1989 and later, Fig. 10).

The definition of landslides involves a concept of excess pore pressure. The cause for a high pore pressure is at the same time an indicator of a landslide mechanism. For Central Yamal we distinguish two different mechanisms of landsliding, two sets of forcing factors, triggers, and landforms. The name of process in reference to the mechanism of landsliding in Table 5 corresponds to the translation of Russian terms (in the parenthesis are more or less equivalent terms used in the English cryogenic-landslide literature).
Cryogenic translational landslides $(C T L)$ result from rapid thaw of ice-saturated deposits at the active layer base (transient layer after Shur 1988). Accumulation of segregation ice at the active-layer base and formation of the transient layer is due to the ALD decrease in the course of several years' cooling. Intensive heat flux in the late summer and heavy rainfalls linked to this period both cause relatively rapid thaw of the icy layer at the activelayer base, with excess water accumulating in the active layer because of the low filtration ability of silty soils, and dramatic rise of the pore pressure. Gravity causes the displacement of blocks, broken up by frost, desiccation, or edge cracks, 'floating' on the layer with excess pore pressure (Leibman \& Egorov 1996). Blocks preserve integrity due to the
Table 5. The mechanisms and classification of cryogenic landslide processes.

\begin{tabular}{l|l}
\hline $\begin{array}{l}\text { Cryogenic translational landslides (active-layer } \\
\text { detachments, block glides) }\end{array}$ & $\begin{array}{l}\text { Cryogenic earth flows (mudflows, retrogressive thaw } \\
\text { slumps) }\end{array}$ \\
\hline $\begin{array}{l}\text { Rather dry and dense sandy-silty active-layer deposits } \\
\text { Result of upward freezing of the active-layer and }\end{array}$ & $\begin{array}{l}\text { Water-saturated viscous-flow silty-clayey active-layer } \\
\text { deposits } \\
\text { subsequent thaw of the ice at the active-layer base }\end{array}$ \\
$\begin{array}{l}\text { Interannual active-layer dynamics } \\
\text { Landslide body is a one piece or broken into several } \\
\text { pieces block with well expressed vertical sidewalls } \\
\text { along the perimeter }\end{array}$ & $\begin{array}{l}\text { Landslide body is a spread flow with parabolic } \\
\text { outlines, floating pieces of turf (sod) with shrubs on } \\
\text { top }\end{array}$ \\
\hline
\end{tabular}



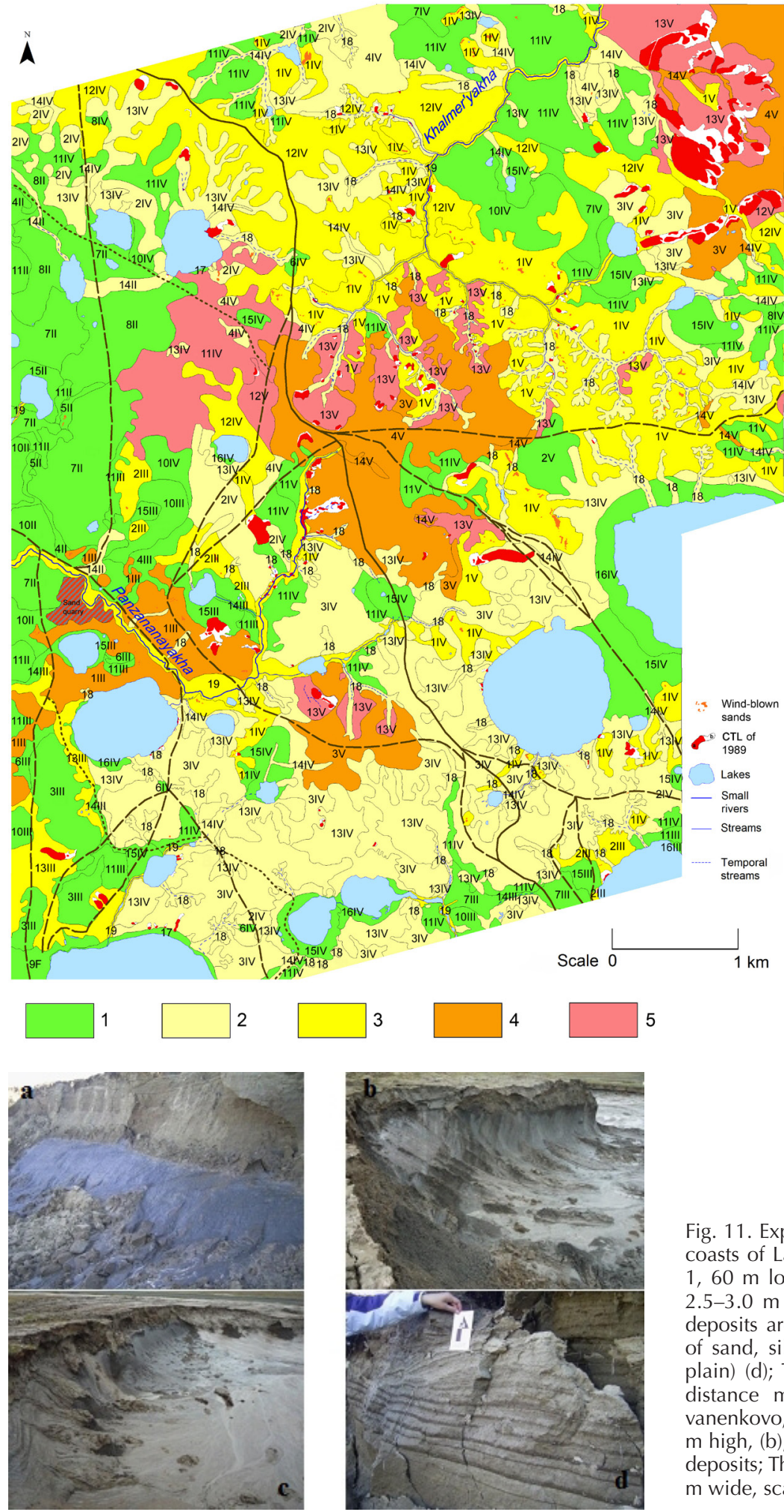

Fig. 10. Map of modern landsliding impact at Vaskiny Dachi. The degree of modern landsliding impact: 1 - none $(0 \%), 2$ low $(0-1 \%), 3$ - medium (1$5 \%), 4$ - high (5-10\%), 5 - the highest $(10 \%$ and more). After A.V. Khomutov $(2010,2012)$.

Fig. 11. Exposures of tabular ground ice at the coasts of Lake Nedarmato: Thermocirque No. $1,60 \mathrm{~m}$ long and $40 \mathrm{~m}$ wide (a), its scarp is 2.5-3.0 m high, covering tabular ground ice deposits are represented by thin interbedding of sand, silt and organic (III ${ }^{\text {rd }}$ alluvial-marine plain) (d); Thermocirque No. 2, 537-538 km distance mark of the railway Obskaya-Bovanenkovo, $166 \mathrm{~m}$ long, $100 \mathrm{~m}$ wide, scarp 4 $\mathrm{m}$ high, (b), covering ice are sandy-silty clayey deposits; Thermocirque No. 3, 120 m long, 50 $\mathrm{m}$ wide, scarp up to $3 \mathrm{~m}$ high (c). 
structural bounds, formed by multiple freeze-thaw, drying-liquefaction and desiccation of the middle portion of the active layer by two-sided freeze back (Lewkowicz 1988, 1990; Leibman 1995).

Cryogenic earth/mud flows CEF(viscoelastic)/ CMF(viscofluid) result from thaw of the massive ground ice. CEF/CMF are also referred to as retrogressive thaw slumps. This type of sliding mechanism is linked to the areas where massive ground ice is close to the surface and occasionally involved in the seasonal thaw through the natural or technogenic disturbance, or noticeable summer warming (Fig. 11). At the exposures, thawing ice causes failures of overlaying deposits liquefied by meltwater and produces mudflows with pieces of turf, floating on top. When the exposures are covered with slope deposits, a portion of meltwater is absorbed by these deposits and earth flows form (Leibman \& Kizyakov 2007).

Differently from CTL, CEF/CMF can develop every year until massive ground ice is within the zone of seasonal thaw. CMFs are formed during the entire warm period in the ice exposures, CEFs form only during warm years, mainly at the end of the warm period under the maximum thaw depth. Rain water is not as crucial for CEF/CMF, because massive-ice melt-water provides enough moisture for the embodiment of the landslide potential on slopes (Kizyakov 2005a; Kizyakov et al. 2006).

Landslide-affected slopes present a specific set of morphological elements (Fig. 12): hill tops and stable slopes, not affected by landslides (background); cirque-shaped depressions, landslide scarp and shear surface (denudation zone); and deformed hillocks and terraces, landslide bodies (accumulation zone).

\section{Radiocarbon dating of cryogenic landslide events}

The dating was applied to determine the time intervals between the stages of landslide development and their connection to climate fluctuations. A test landslide cirque (Fig. 2, site 2) was chosen to date a series of landslides with different stage of re-vegetation and preservation of landslide elements, such as the shear surface, scarp, front wall. The dating of each landslide event within one slope system shows the time needed for 'preparation' of the slope for the new active-layer detachment, in coincidence with specific climate conditions. The 'preparation' period is needed for: (a) the formation of a transient

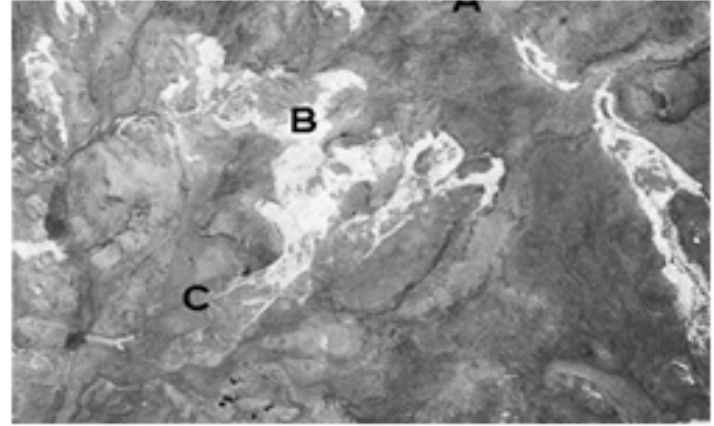

Fig. 12. Landslide-affected slope on the aerial photo: B, landslide shear surface; and C, landslide body.

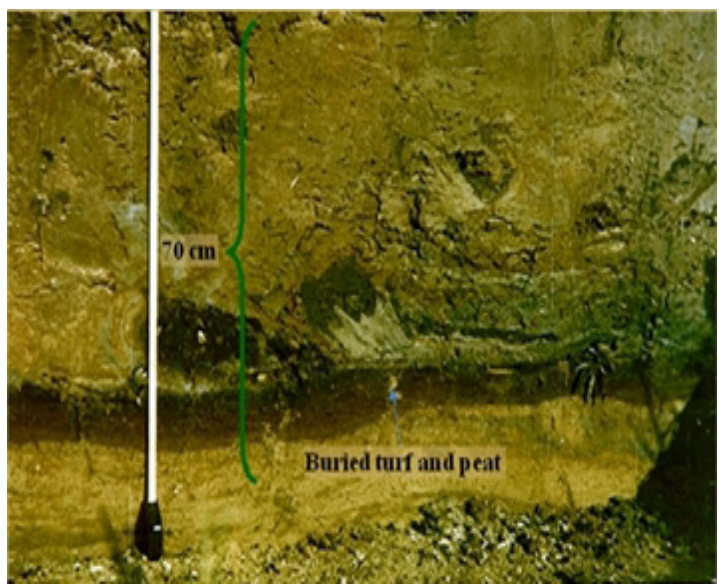

Fig. 13. Organic matter (ground cover and peat) buried by a landslide body (Photo by Leibman).

layer at the active-layer/permafrost interface, at least one cold and wet summer preceding the next colder summer with a less seasonal thaw, (b) the restoration of vegetation and strength of the organic mat, which maintains deposits as a single rigid body, resistant to strain except along the shearing zone, (c) the leveling of erosion channels formed during the first several years on the shearing surface of the previous landslide and providing good drainage, for better moisture saturation and high pore pressure.

Turf-soil-vegetative layers buried by a landslide body are found in the profile (Fig. 13). Radiocarbon dating was undertaken to date ancient landslides with poorly expressed features. Buried turf, humus, peat and willow branches were analyzed. Laboratory ${ }^{14} \mathrm{C}$ tests were performed at the isotope 
geochemistry and geochronology laboratory of Geological Institute of the Russian Academy of Sciences (GIN RAS), Moscow, by L.D. Sulerzhitsky with the assistance of A.I. Kizyakov and N.E. Zaretskaya (Table 6, Leibman et al. 2000, 2003; Leibman \& Kizyakov 2007).

The most ancient date obtained at the landslide cirque from a depth of $78-81 \mathrm{~cm}$ has a ${ }^{14} \mathrm{C}$ age of $2250 \pm 100$ yr BP (GIN-11300, Table 6). In the same pit, at 45-64 cm depth, the second horizon of buried soil showed an average ${ }^{14} \mathrm{C}$ age of $1880 \pm 120 \mathrm{yr}$ BP (GIN-11299). The proximity of the age of this soil to date obtained in the other pit $(1790 \pm 140 \mathrm{yr}$ $\mathrm{BP}, \mathrm{GIN}-10315)$ suggests that a single soil unit was buried by a landslide of the second generation.

The third stage of the landslide cirque development happened $1360 \pm 40$ yr BP (GIN-10316, Table 6). Two more dates were obtained in one profile: $1000 \pm 60$ yr BP (GIN-11301), and $700 \pm 40$ yr BP $(\mathrm{GIN}-11302)$. The final stage before present was found to be $330 \pm 40 \mathrm{yr}$ BP (GIN-11298).

Thus the cycles of landslide development in a single landslide cirque were presumed with the time intervals between the stages of 290-460 years (Table 7).

Table 6. The results of radiocarbon dating by GIN RAS (Leibman et al. 2003).

\begin{tabular}{ccccc}
\hline $\begin{array}{c}\text { Pit \# } \\
\text { (Fig.II.5) }\end{array}$ & Depth, cm & Material & ${ }^{14}$ C Age, years BP & Laboratory Code \\
\hline AK9 & $82-88$ & peat & $1060 \pm 70$ & GIN-10314 \\
AK13 & $40-45$ & peat & $1790 \pm 140$ & GIN-10315 \\
AK15 & $57-67$ & peat & $1360 \pm 40$ & GIN-10316 \\
AK16 & $42-51$ & peat & $700 \pm 40$ & GIN-10317 \\
AK16 & $42-51$ & wood & $330 \pm 40$ & GIN-11298 \\
AK22 & $45-64$ & humus & $2250 \pm 100$ & GIN-11299 \\
AK22 & $78-81$ & humus & $1000 \pm 60$ & GIN-11300 \\
AK23 & $48-54$ & humus & $700 \pm 40$ & GIN-11301 \\
AK23 & $63-65$ & humus & & \\
\hline
\end{tabular}

Table 7. The cycles of landslide development in the experimental landslide cirque determined by radiocarbon dating.

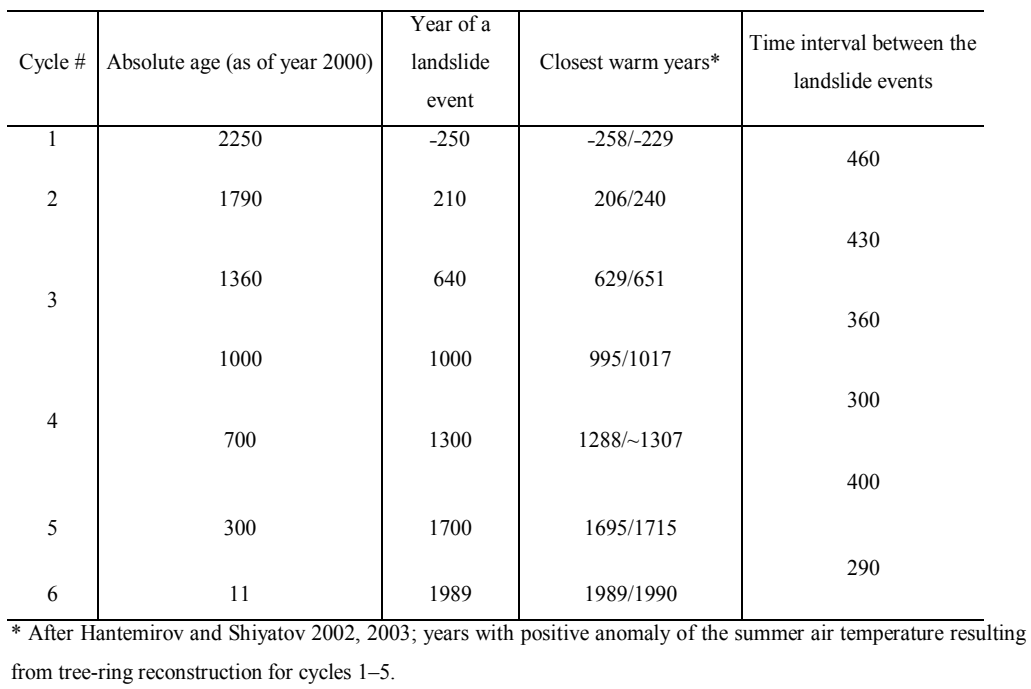




\section{Dendrochronology}

Willow shrubs are no older than 100 years. They cannot be used to determine the stage of landslide events, but they can be used to estimate the impact of landslides on their growth and thus determine single recent events. Thus, the analysis of ring width was undertaken in relation to summer temperature and position on the morphological element of a landslide slope.

The age of willow branch slices, collected by $M$. Leibman and A. Kizyakov, was determined by L.A. Gorlanova in the Institute of Plant and Animal Ecology, Ural Branch of the Russian Academy of Sciences according to the methods developed by Shiyatov and Gorlanova (1986), Hantemirov and Shiyatov (2002, 2003), Gorlanova (2002) and Leibman et al. (2003).

Study objects were willow shrubs Salix lanata L and S.glauca L, as well as Betula nana L. As the root systems of the shrubs in permafrost are close to the surface in the active layer, active-layer detachments allow willows to continue growing in the new place while the detachment and change of the position affects annual rings' width and shape.

Samples from the young landslides of known age allow studying the mechanisms of landslide impact on willow annual rings due to direct observations. Samples from ancient landslides can be interpreted using results obtained at the dated landslides (Leibman et al. 2000, 2003; Gorlanova 2002). Sampling was undertaken along the transects starting on the stable surface of the hilltop and continuing down across the slope (shear surface and landslide body, its front swell and ends at the undisturbed foot slope). Slices of the branches, subterranean stems and tillering nodes at the shrub base were analyzed. Diagrams of annual growth were built, and cross-dating performed for samples of different parts of one shrub (Gorlanova 2002).

120 slices of 55 willow and dwarf birch shrubs were examined. It was found that the ring pattern reflect both favorable and poor conditions for growth depending on the position against the morphological unit of the landslide as well as local fea-

Table 8. Criteria for landslide dating by tree-ring method (after L.A.Gorlanova 2002)

\begin{tabular}{|c|c|c|c|}
\hline $\begin{array}{l}\text { Tree-ring } \\
\text { pattern }\end{array}$ & Growth controls & $\begin{array}{l}\text { Landslide } \\
\text { element* }\end{array}$ & Years and number of samples with observed tree-ring pattern \\
\hline \multirow{7}{*}{$\begin{array}{l}\text { 1. Sharp } \\
\text { decrease in } \\
\text { annual growth } \\
\text { speed and } \\
\text { mechanical } \\
\text { injury of roots } \\
\text { and branches }\end{array}$} & \multirow{4}{*}{$\begin{array}{l}\text { Changes of soil, } \\
\text { hydrology, and } \\
\text { irradiation, the } \\
\text { deformation of a }\end{array}$} & A1 & $1970,1980,1988,1989$ \\
\hline & & $\mathrm{A} 2$ & 1924, 1953 (2), 1954 (2), 1956, 1982, 1989, $1990(4)$ \\
\hline & & B3 & 1957 (2), 1959, 1965, 1967, 1971 (2), 1977, 1978, 1980 (2), \\
\hline & & & $1981,1986(2), 1989(2), 1990$ \\
\hline & $\begin{array}{l}\text { landslide body } \\
\text { during movement }\end{array}$ & $\mathrm{C} 1$ & 1989,1990 \\
\hline & \multirow[t]{2}{*}{ down the slope } & $\mathrm{C} 3$ & 1952, 1956, 1957 (2), 1964, 1975, 1976, 1977 (2), 1980 (2), \\
\hline & & & $1986,1987,1988(2), 1989(2)$ \\
\hline \multirow{6}{*}{$\begin{array}{l}\text { 2. Sharp } \\
\text { increase in } \\
\text { annual growth } \\
\text { speed and } \\
\text { formation of } \\
\text { new sprouts }\end{array}$} & \multirow{6}{*}{$\begin{array}{l}\text { The rootage of } \\
\text { branches, } \\
\text { improvement of } \\
\text { soils and water- } \\
\text { thermal regime }\end{array}$} & A1 & $1957,1970,1981$ \\
\hline & & $\mathrm{A} 2$ & $1922,1987,1990(2)$ \\
\hline & & B3 & 1923, 1955, 1960, 1961, 1981 (2), 1990 \\
\hline & & $\mathrm{C} 1$ & 1982,1990 \\
\hline & & $\mathrm{C} 3$ & $1925,1927,1929,1953,1954,1955,1956,1957,1972,1981$ \\
\hline & & & (2), 1982, 1988, 1989, 1990 \\
\hline \multirow[t]{5}{*}{ 3. No response } & No relation & A1 & no \\
\hline & \multirow{3}{*}{$\begin{array}{l}\text { between the } \\
\text { growth conditions }\end{array}$} & A2 & 5 \\
\hline & & B3 & 2 \\
\hline & & $\mathrm{C} 1$ & no \\
\hline & and landslide & $\mathrm{C} 3$ & 4 \\
\hline
\end{tabular}

* A1 - Stable surface close to the landslide scarp; A2 - The same, far from the landslide scarp; B3 - Re-vegetated surface of the ancient landslide shear surface; C1 - A body of a young landslide; C3 - A body of an ancient landslide. 
tures (cracks, folds, drainage or moisturizing). The criteria for landslide dating are shown in Table 8.

From Table 8 it follows that on the young landslides (those of 1989) there are sharp changes in the annual growth in the year of the landslide event and the next year, both positive and negative in various parts of the slope (Leibman et al. 2014). Correlation of the tree-ring growth curves with the normalized summer temperature (derived from dividing the average summer temperature of each year by the average for the period of observation, Leibman \& Egorov 1996), as well as with the normalized summer precipitation, according to weather station records, shows the following: both high summer temperature and high summer precipitation as a rule are favorable for annual growth speed. Yet, the highest number of samples with maximum and minimum growth speed does not always correlate with the highest and lowest summer temperature and precipitation. For example, many samples with the positive annual growth response are noted in 1990, 1981, 1953 and 1970 while normalized summer temperature in the same sequence decreases: $95,74,79$ and $45 \%$ of maximum. At the same time, precipitation in the same sequence change as follows: 60, 29, 77 and $32 \%$ of maximum.

An essential number of samples with the negative growth speed are noted in 1989, 1990, 1980 and 1957. These years are characterized with the norm of summer temperature equal to $95,95,41$, and $82 \%$, respectively (for precipitation $82,60,39$ and $49 \%$ ). Thus, being one of the highest, summer temperatures in 1989-1990, also characterized by high summer precipitations, resulted in the decrease of the ring growth speed instead of an expected increase, which doubtlessly was a result of hazardous activation of landsliding in 1989.

The tree-ring growth speed analysis allows the conclusion that there have been earlier events in 1980 (with positive response in 1981) in the landslide cirques under study in addition to the known landslide event of 1989 (with a positive response in 1990). Possibly, the negative response of treering growth speed in the relatively warm year 1957 was also connected to the landslide activation.

\section{Geochemical consequences of cryogenic landsliding}

Cryogenic landslides on the Yamal Peninsula periodically modify slopes of the dissected Middle to
Upper Pleistocene marine plains, by removing washed out active layer soils and bringing saline marine deposits to the surface. The mesorelief is characterized by the cascades of shear surfaces alternating with lumpy landslide bodies. Often numerous multi-aged landslides join to form semibowl-shaped depressions (landslide cirques).

During the first several decades after the landslide event, vegetation is still very sparse on the shear surfaces and the soil cover is not yet formed. Bare clayey surfaces are saline with evaporates, and are sparsely covered by Gramineae and chamomile during dry periods (Rebristaya et al. 1995; Leibman et al. 2000; Ermokhina 2009). Desalinization of the active layer starts immediately after the landslide event. Migration of ions to the surface, and then washing away of evaporates by rain water and surface runoff, is the main mechanism of desalinization (Leibman \& Streletskaya 1996, 1997; Streletskii et al. 2003). Subsurface runoff also contributes to the washing of saline deposits in relation to post-cryogenic fissuring at the active-layer base that causes high permeability in clay (Leibman et al. 2000, 2003; Leibman \& Kizyakov 2007).

The geochemical consequences of cryogenic landsliding are observed when studying ground and surface waters, soils and vegetation of the landslide shear surfaces. One of the landslides of 1989 (Fig. 2, site 13) was chosen to study the redistribution of ions in the active layer newly exposed by a landslide. The vertical migration and horizontal wash away of readily soluble salts started after the landslide event (Leibman \& Streletskaya 1996; Tentyukov 1998; Ukraintseva et al. 2000). Samples were collected from the core of shallow boreholes and their ion composition was tested to analyze the redistribution of water-soluble salts in the newly formed active layer. The same landslide area was under study in summer 2001. The results of repeated chemical tests have been compared and revealed the dynamics of the ionic migration through a geological section. It was established that there are two horizons of salinization. Nearsurface salinization is due to the salt migration upward in winter (Naletova 1996) and capillary rise in summer (Anisimova 1981). The second, near the active layer base, is resulting from the accumulation of salts on a geochemical barrier of permafrost table serving as an aquifuge (Leibman \& Streletskaya 1996). The lower horizon at the active layer base of the wet site loses its salts due to the subsurface runoff through the post-cryogenic cracks where the rate of filtration is abnormally high 


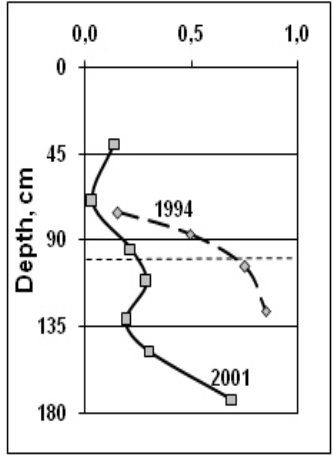

a

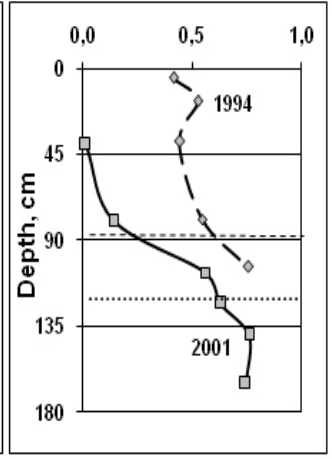

b

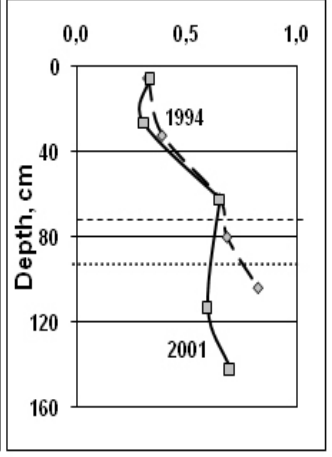

C
Fig. 14. Total concentration of soluble salts (a dry residue) in the deposits of the active layer and upper permafrost at: undisturbed site (borehole 1, 2001) (a); wet site of the shearing surface (borehole 2 in 1994 and 2bis in 2001) (b); and at the dry site of the shearing surface (borehole 3 in 1994 and 3bis in 2001) (c).
(Leibman et al. 1993a, 1993b; Naletova 1996). At the wet site, the salt content is much less in 2001 compared to 1994.

The most active desalinization is above the active layer base of 1994. This can be explained by abundant cracking in the active layer of the wet site, the better developed post-cryogenic fissured zone, and thus more intensive run-off. The upper accumulation zone in 2001 should be much less pronounced compared to 1994 due to the re-vegetation of the surface and prevention of wash out of evaporites.

The dynamics of total salinity on the dry shearing surface are characterized by the binomial accumulation pattern. The upper accumulation horizon is less expressed while the active layer base horizon shows the highest content of soluble salts among the study sites. Most likely this can be explained by an accumulation at the geochemical barrier under low run-off and the lack-of-water conditions of the dry site. The redistribution of separate ions (mainly anions) is different from the total soluble-salt redistribution, depending on the migration ability of anions. Cations are not discussed because their distribution pattern with depth does not change qualitatively, though the content of cations decreases. As an example, total salinity diagrams are shown in Figure 14.

Bicarbonate content decreased at both sites in 2001 compared to 1994, but to a larger degree at the wet site. The accumulation zone for sulfate-ion at the geochemical barrier is the most expressed at the wet site where the maximum is noted at the active layer base of the relevant year. Remarkable is the abrupt increase of sulfate content on the sur- face of the dry site. This is explained by several reasons: (1) the capillary rise of soluble salts is more active at the dry site, (2) chlorides are the most mobile and first to be washed away, and (3) the content of bicarbonates is low from the beginning. Thus, sulfates are the main component of evaporites on the surface of the dry site. The total content of chloride-ion is the highest among other anions due to the marine type of initial salinization in the studied deposits. The main distribution pattern is the persistent decrease with depth up to the active layer base. Chloride content in permafrost does not change much in 2001 compared to 1994, but there is a rather high difference at the active layer of the wet site or near the surface at the dry one between 1994 and 2001. Thus, the geochemical barrier at the active layer base for this anion is not efficient. Capillary rise is, probably, the main factor of redistribution for chloride. As demonstrated by the field study, the change in content of cations and anions between 1994 and 2001 follows the migration rates of various ions. On undisturbed surfaces, all anions have the same distribution pattern with the maximum in the zone of maximum seasonal thaw depth (geochemical barrier); at the shearing surface this regularity is impeded by the redistribution of chloride-ion. This ion moves fast from permafrost into the active layer due to a high migration rate and is washed away by surface and active layer runoff. Sulfate and bicarbonate form a second zone of accumulation at the depth of 20$30 \mathrm{~cm}$. This zone is the most expressed at the dry site and more actively reducing at the wet one due to a higher runoff. Chloride marks this zone by a reduced rate of washing away. 


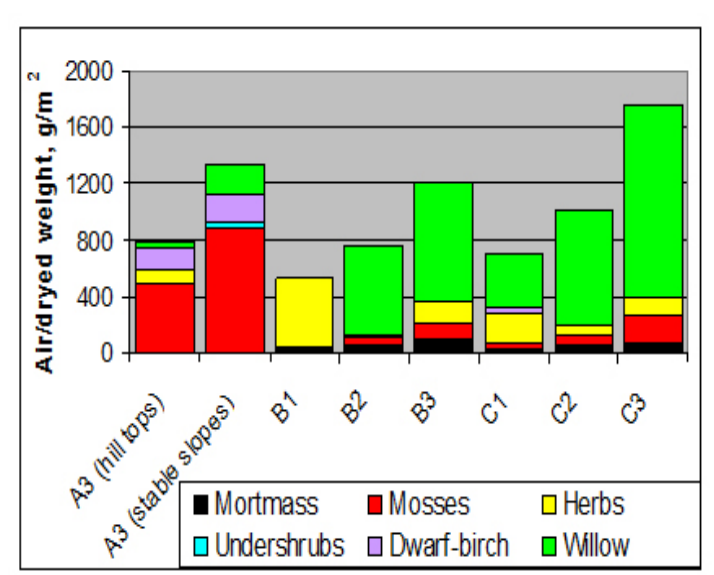

Fig. 15. Above-surface phytomass of vegetation cover at landslide-affected slopes and 'background' surfaces, where 1,2 , and 3 refer to modern, old and ancient landslides, respectively (after N.G. Ukraintseva in Ukraintseva \& Leibman 2007).

Thus, a shearing surface compared to an undisturbed slope is characterized by the reduced content of soluble salts in both the active layer and upper portion of permafrost, so the landslide process causes the desalinization of near-surface saline marine deposits. The initially marine type of salinization in perennially frozen deposits involved in the seasonal thaw after the landslide event turns into continental (when chlorine-sodium-potassium ions are replaced by hydrocarbon- ate-sulfate-calcium ions due to a high rate of washing away chloride and sodium.

\section{Soil and vegetation geochemistry}

The geochemistry of vegetation, soil and ground water was under study at the test landslide cirque (Fig. 2, site 7). Figure 15 shows that the stable surfaces are characterized by the prevalence of moss as a source of biomass while landslides, both shear surfaces and bodies, are represented by willows, except young shear surfaces where only pioneer herbs appear. Succession of mosses can be followed from young (C1) to ancient (C3) landslide bodies. The explanation is found in the dynamics of soil nutrition. Nutrients content is increasing from stable surfaces to landslides and from young landslides to ancient ones (Fig. 16).

Ground water and soils within the landslides show the highest concentration of soluble salts on young shear surfaces because marine deposits have been exposed recently by a landsliding. They are built of clayey deposits which are hard to wash out, and also they are frozen for at least 8 months a year. For this reason high mineralization in the active layer and ground water lasts for decades. Even ancient shear surfaces, older than 300 years of exposure to washing, have much higher soluble salt concentration than stable surfaces. Landslide bodies are enriched in salts through the ground water filtration downslope. While stable surface soils are alkaline, landslide elements are mostly acidic.

Due to additional nutrients and thick winter snow cover within the concave shear surface of landslides,
Fig. 16. Nutrients (Organic Carbon, Corg, and Nitrogen, N) in soils within the landslides (after N.G. Ukraintseva in Ukraintseva \& Leibman 2007).

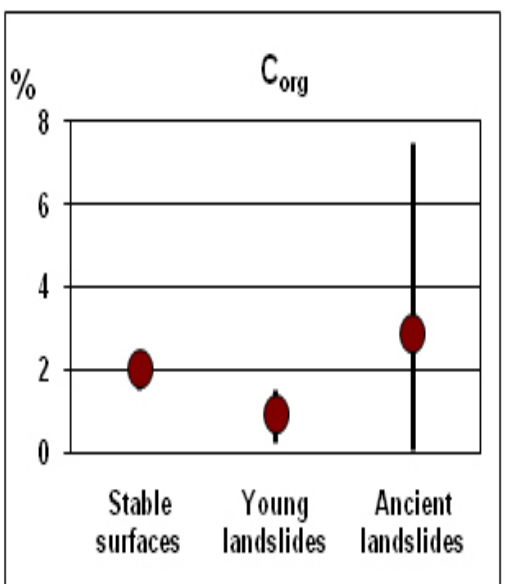




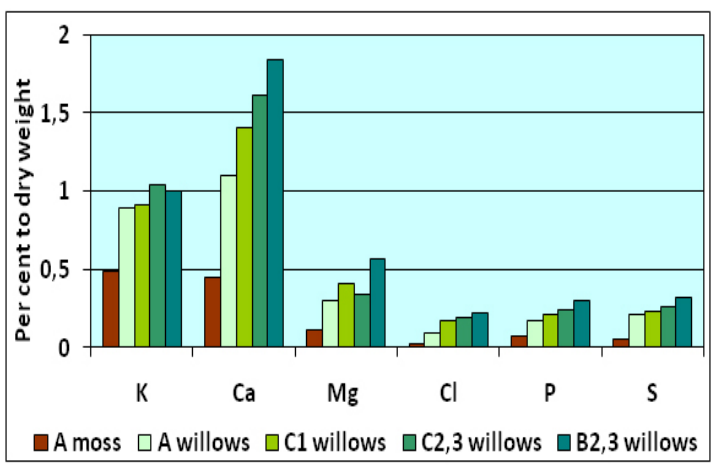

Fig. 17. The average concentration of chemical elements (Potassium, K; Calcium, Ca; Magnesium, Mg; Clorine, Cl; Phosphorus, $\mathrm{P}$ and Sulfur, $\mathrm{S}$, in per cent to dry weight) in dominant biomass-constitutive material: moss (sparse willow shrubs in addition) on stable surface (A), and willow shrubs (leaves) within an etalon landslide cirque (C1 - young landslide body; C2, 3 - ancient landslide body; B2, 3 - ancient shear surface) (Ukraintseva \& Leibman 2007).

high willow thickets develop. They occupy old shear surfaces, appear after several decades from the landslide event, when aggressive marine salts are partly evacuated from the active layer. Willow shrubs provide more nutrition than typical-tundra vegetation like moss-lichen-grass communities due to the leaf litter. Biomass measurements show that main biomass on the stable surfaces is due to moss-lichen cover while on landslides the bulk of biomass is provided by willow shrubs (Ukraintseva \& Leibman 2007; Ukraintseva et al. 2014).

The ratio of some chemical elements determined in all plants and plant parts also shows that nutrition on landslide surfaces is provided by willows. Figure 17 presents a comparison of moss and willow chemistry of a stable surface, as well as willow leafs in various parts of landslides of various ages. Maximum concentration is found at ancient landslides, both shear surface and landslide body.

For all the elements considered here (Fig. 17), their concentration in plants on stable surfaces is lower than on landslides. Shrub leaves contain higher concentration of all elements than moss. Most elements show higher concentration on ancient landslide shear surfaces compared to bodies, and on ancient landslide bodies compared to young ones (Ukraintseva \& Leibman 2007; Ukraintseva et al. 2014).

Soils on a landslide shear surface have favorable agrochemical properties compared to the stable surface due to the impact of saline marine substrate ex- posed by landslides and involved in the seasonal thaw. Willow shrubs are the main source of biological productivity. They utilize chemical elements from marine substrate on landslide shear surfaces.

\section{Prediction and assessment of cryogenic landslide activation}

The mapping of landslides and prediction of their activation is based on a key-landscape method most widely used in Russian permafrost studies (Yershov 1998). Several landscape maps were compiled for the VD area. The latest one using GIS and remotesensing technologies is presented on Figure 18.

To analyze a landslide hazard, geomorphic units with specific geology, topography, and slope length were subdivided. Then, landforms where cryogenic landsliding activation is probable were assigned. Separated were subhorizontal surfaces and bottoms where cryogenic landslide formation is impossible, and tops where landslides are improbable. The analysis of landslide pattern shows that all modern cryogenic landslides are located on concave slopes which means that they occupy ancient landslide slopes. However, new landslides are less probable on concave slopes already affected by modern landsliding than on concave slopes with only ancient landslides. To analyze modern landsliding impact, 19 landscape complexes were subdivided within the study area (Fig. 18). Landscape complexes are combined to 5 groups according to the modern landsliding impact (Fig. 10). Generally, the impact of modern landsliding on landscape complexes increases from low (IInd-III $\left.{ }^{\text {rd }}\right)$ to high $\left(I V^{\text {th }}-V^{\text {th }}\right)$ geomorphic levels. The maximal landsliding impact occurred on concave ancient landslideaffected slopes and gentle slopes with tussocky shrub-sedge-moss cover on the $\mathrm{V}^{\text {th }}$ Marine plain. These landscape complexes are characterized by a maximal area affected by active layer detachment slides of the 1989 landsliding event (16 and 20\%, respectively). A cryogenic landsliding hazard degree map was compiled based on the analysis of modern landslide coverage within different landscape complexes and geomorphic levels (Khomutov \& Leibman 2014).

Very high cryogenic landsliding hazard on concave shrubby slopes is characteristic of all geomorphic levels except the Mordy-Ykha river flood plain and the $2^{\text {nd }}$ river terrace. The risk of largescale landsliding on gentle shrubby/partly shrubby slopes increases from low to high geomorphic lev- 

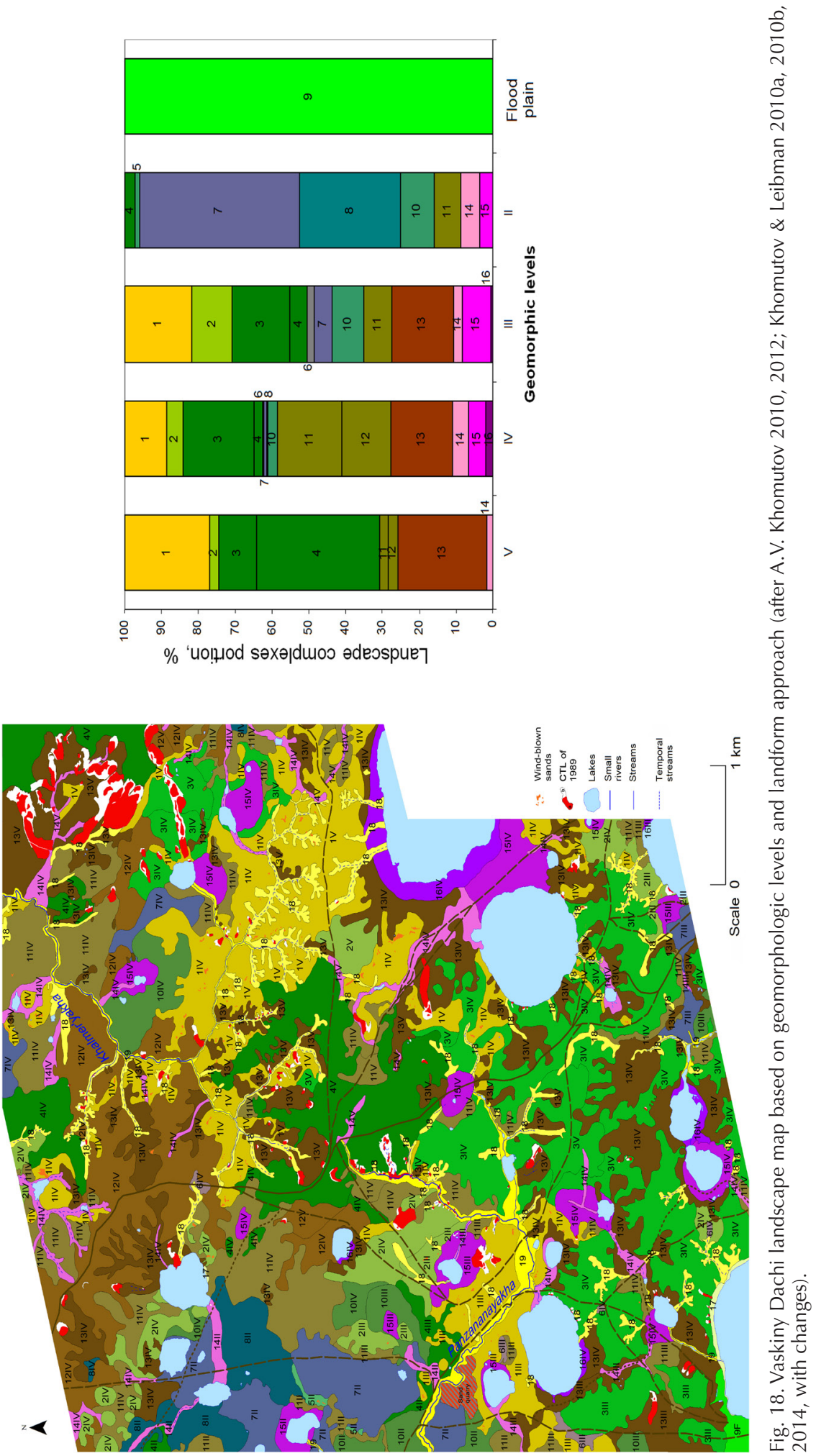
els. Small-scale landsliding on tentatively horizontal surfaces increases with the degree and depth of dissection by ravine and small stream valleys independently of geomorphic level. Cryogenic landslide formation is impossible on subhorizontal surfaces and bottoms, and landslides are improbable on tops. Surfaces affected by modern landsliding are not in a risk of activation of cryogenic landsliding because the icy transient layer did not form yet at the bottom of the 'new' (after the active layer detachment) active layer.

\section{Activation of thermal denudation in 2012- 2013}

We suggested that cryogenic translational landslides resulting from accumulation of ice at the active layer base will not become more active because of climate warming as they depend on reduction of the active layer thickness in a sequence of years. This assumption is based on our theory subdividing 2 main types of cryogenic landslides differing in mechanisms and triggers: (1) translational landslides, and (2) earth flows. At the same time, earth flows/mud flows related to the thaw of ground ice within permafrost should be activated with the deepening of the active layer when massive ground ice is involved in thawing. This theoretical assumption was verified in 2012 and especially in 2013 when extremely warm summers resulted in a substantial deepening of the active layer (average values on the test grids were the highest in 2012-2013 (102-103 cm) compared to previ-

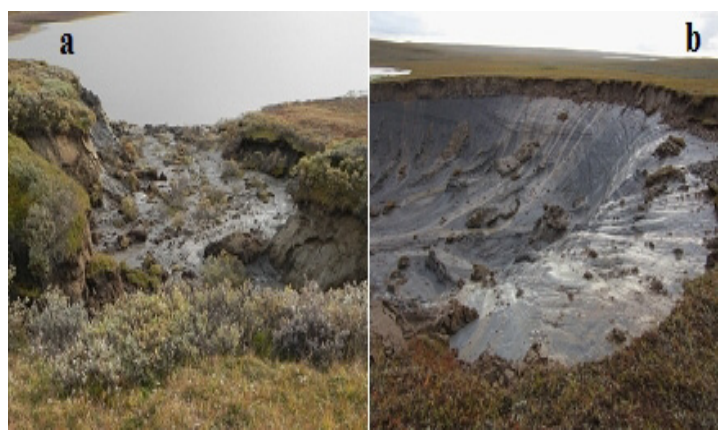

Fig. 19. Thermocirques formed due to earth/mud flows in 2012 (a) and expanded in 2013 (b) (Photo by Leibman and Dvornikov). ous years (76-97 cm in 1993-2011). As a result, a number of new landslides appeared, only a few being translational landslides (active-layer detachments). Most landslides were earth and mud flows.

Monitoring in 2012-2013 revealed extraordinary large exposures of buried polygonal ice wedges invading into tabular ground ice in the area. Buried peat several meters thick was also exposed in the sections building polygonal blocks in between the ice wedges. Such exposures are very unusual for this inland area. They are mostly observed and described at the sea and river exposures. Ice wedges do not have manifestations on the surface except for subdued polygonal relief at the hill edges. It is for the first time since Yamal was under such a close study that such sections are found inland.

While translational landslide events are separated by several centuries and form landslide cirques, earth/mud flows form thermocirques which, once being triggered, develop until either ice is exhausted or insulated by landslide bodies from further thaw. Single translational landslides and earth/mud flows are found as well. Usually single earth flows are located on slopes far from the impact of streams or lakes while thermocirques are rather related to lake coasts. Several thermocirques exposed walls up to $15 \mathrm{~m}$ high and hundreds of meters long. The rate of scarp retreat reached several tens of meters a year since discovered in 2012 (Fig. 19).

Thus, the activation of cryogenic landsliding in Central Yamal proved the theory which suggests that earth flows are landslide forms extending over territory with massive ground ice due to climate warming.

\section{Cryogenic and hydrologic processes in a small river basin (Panzananayakha)}

More than $90 \%$ of the rivers in Yamal tundra are less than $10 \mathrm{~km}$ long. Such small rivers comprise over $80 \%$ of the total length of all rivers. The same scale of cryogenic and hydrologic processes for just small catchments is the main reason for the relation and interaction of hydrologic and cryogenic processes. On medium-length and long rivers, an impact of cryogenic processes directly on a channel is not observed since even the fastest and sizable mass waste processes are not capable of changing the stream direction or even 


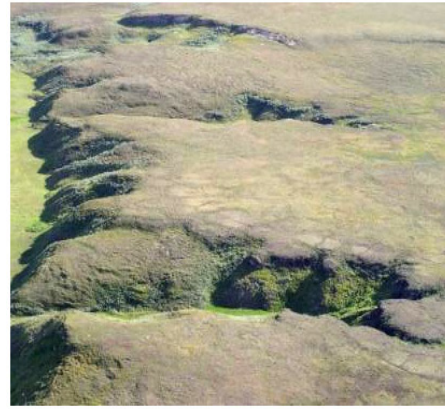

a

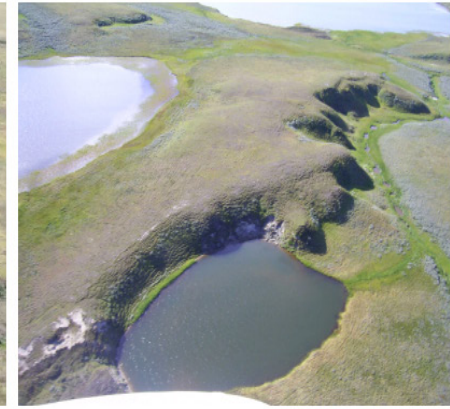

b

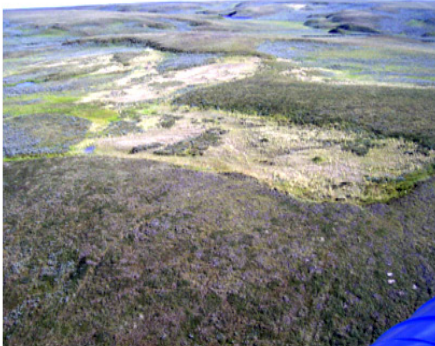

C

Fig. 20. Cryogenic processes affecting small river valleys: ravine (lateral) thermoerosion (a); thermokarst (b); and cryogenic landslides (c) (Gubarkov \& Leibman 2008a, 2008b). (Photo by Leibman and Khomutov).

partially dam the water flow as it happens in small river channels (Gubarkov 2009, 2011a; Gubarkov \& Andreeva 2011).

The main cryogenic process, affecting water and sediment runoff of the small rivers in Vaskiny Dachi, is ravine thermoerosion (Fig. 20a), thermokarst (Fig. 20b), and cryogenic landslides (Fig. 20c).

Investigations of the cryogenic landsliding in Yamal (Leibman \& Kizyakov 2007) show that the water and sediment runoff as well as the evolution of channels and valleys of small rivers are mostly influenced by landslides (both active-layer detachments and earth flows). The important features of landslides are the speed of the landslide descent, the volume of the landslide body, and the position on the valley slope. This last feature determines the possibility of the landslide body to block a valley and a channel of a small stream resulting in the formation of a temporary dammed lake.

\section{Test river Panzananaykha catchment: description and methods}

At Vaskiny Dachi, a small river Panzananayakha was chosen for the study of cryogenic and hydrological processes' interrelation (Gubarkov 2006, 2007, 2009, 2011a, 2011b; Gubarkov \& Leibman 2007, 2008a, 2008b, 2010; Gubarkov et al. 2006, 2012; Gubarkov \& Andreeva 2011). This river represents the small rivers of Yamal as its length is close to the average of Yamal rivers ( $7 \mathrm{~km}$ while the average is $6.99 \mathrm{~km}$; the area of the basin is 7.37 $\mathrm{km} 2 \mathrm{while}$ the average for the region is $11.7 \mathrm{~km} 2$ ). The quantity, length, width and depth of beadshaped channel forms are determined along the entire river channel, as well as within specific portions of the channel. Dominating cryogenic processes, affecting the river channel, differ depending on morphology. In V-shaped valleys, its slopes descend directly into the channel. Thus, the influence of cryogenic landsliding on hydrologic processes dominates here. Ice wedges close to the surface produce bead-shaped channels where 'beads' slow down water cycle in the streams (Gubarkov \& Leibman 2010). Cryogenic processes form specific features of sediment transport as well. The complexes of cryogenic and hydrologic processes, characteristic for upper, middle and lower stream courses in the small catchments, are specified (Fig. 21). Channel processes are bottom and lateral thermoerosion. Trans-catchment processes are transitional landslides and earth flows, and ravine thermoerosion.

Land-based studies were done in 2005-2010 and applied to determine the features of beadshaped river-channel forms: width, length and depth were measured, as well as stream speed. The turbidity factor was measured both in the small- and middle-sized rivers (Gubarkov \& Leibman 2010; Gubarkov et al. 2014). This was done by water sampling, filtering, drying and weighing the dried solids. Hydrological and cryogenic features were counted and measured using maps and aerial photos, and then evaluated by field measurements. 


\section{Erosion and sediment runoff on slopes and rivers}

In some years, the spring erosion on slopes may cover up to $75 \%$ of the annual erosion (Dan'ko 1982) which means that most of the erosion action is confined to frozen deposits (thermoerosion): both active-layer deposits and permafrost are in frozen state. In late summer-fall period, as mentioned above, the thermoerosion and erosion are limited by the active-layer properties and vegetation cover. However, the cryogenic landsliding processes are the most active promoting the majority of thermoerosion and erosion events during this period.

After the landslide shear surfaces are exposed and subjected to heavy erosion and thermoerosion, significant amount of sediments are delivered into the stream network. Under the influence of temporary stream, thermoerosion ravines and troughs develop in a specific sequence. Three zones of thermoerosion are subdivided down the slope as follows: sediment mobilization, sediment transition and sediment accumulation (Gubarkov \& Leibman 2007).

\section{Cryogenic controls of the Panzananayakha river valley formation}

The cryogenic factors not only increase the sediment runoff, but also reduce it. For instance, the reduction of the sediment runoff in small rivers occurs when bead-shaped and dammed river channel features are formed resulting from polygonal structures and landsliding, respectively. Sediment runoff was as high as $5120 \mathrm{~g} / \mathrm{m}^{3}$ resulting from the activation of erosion and thermoerosion in the upper stream of Panzananayaha river in August 2007. In the middle course, sediment runoff reduced to 3 $\mathrm{g} / \mathrm{m}^{3}$ because of the precipitation of sediments in the bead-shaped features.

In the majority of the small rivers with active cryogenic processes at the river banks, the sediment fans are formed at the ravine mouths while landslide bodies often descend to the valley bottom and into the channel. Erosion and thermoerosion fan size is comparable with the width of the valley bottom and river channel and the lifetime of these fans is longer compared to the dammed lakes resulting from landslide activity.

The dams are $2-3 \mathrm{~m}$ high and they are formed out of the landslide bodies loaded in the valley bottom and small river channels. They prevent any sediment transport downstream. After the dams' breakout on the former flooded valley bottom, sheet runoff prevails over linear runoff that does not promote erosion, and also slows the sediment transport. The upper course of the test river Panzananayakha and river Halmeryakha in the study area show such features.

\section{Paragenesis of cryogenic and river-channel processes}

In small river catchments the paragenesis of channel and cryogenic processes occurs all over. Small rivers with intensive linear and side erosion trigger landsliding which produces dammed lakes. These lakes' lifetime lasts for several years prolonging water cycle time by two to four orders of magnitude (Table 9). Thus on small streams even a single landslide event may control the river runoff for several years. Polygonal ice-wedge features are subject to thermokarst resulting in bead-shaped channels. Bead-shaped ponds last much longer compared to the dammed lakes and thus being also larger in volume have a major impact on the water

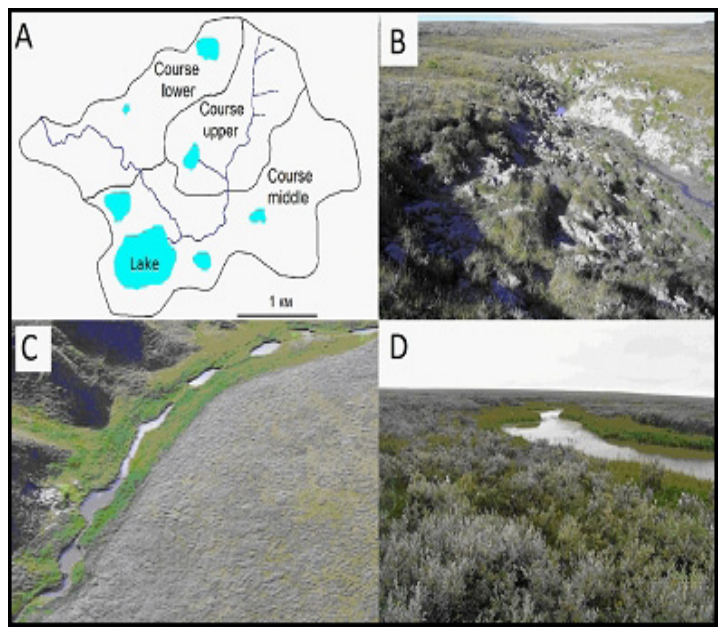

Fig. 21. The Panzananayaha river catchment. A - the scheme of the basin (permanent and temporary water flows). Photos of the Panzananayaha river stream courses with active cryogenic and hydrologic processes in parentheses: B - upper (thermoerosion, cryogenic landslides), C - middle (beadshaped channel forms), and D - lower (water flows) (after A.A. Gubarkov in Gubarkov \& Leibman 2008a, 2010). (Photo by Gubarkov). 
Table 9. Cryogenic and hydrometric features measured in the upper, middle and lower course of Panzananayakha river (after Gubarkov 2007, 2009; Gubarkov \& Leibman 2008a, 2008b).

\begin{tabular}{|c|c|c|c|c|c|c|}
\hline $\begin{array}{l}\text { Distance of the } \\
\text { section line from the } \\
\text { river head, km }\end{array}$ & $\begin{array}{l}\text { River } \\
\text { course }\end{array}$ & $\begin{array}{l}\text { Water } \\
\text { discharge, } \\
\mathrm{m}^{3} / \mathrm{s}\end{array}$ & $\begin{array}{l}\text { Volume of } \\
\text { bead-shaped } \\
\text { forms, } \mathrm{m}^{3}\end{array}$ & $\begin{array}{l}\text { Volume of } \\
\text { dammed } \\
\text { lakes, } \mathrm{m}^{3}\end{array}$ & $\begin{array}{l}\text { Time of } \\
\text { water } \\
\text { cycle, } \\
\text { hour }\end{array}$ & $\begin{array}{l}\text { Cryogenic/ hydrological } \\
\text { features observed upstream } \\
\text { from the section line }\end{array}$ \\
\hline 1.5 & Upper & 0.005 & 0 & 0 & 3 & None \\
\hline 1.5 & Upper & 0.005 & 205 & 0 & 11 & $\begin{array}{l}\text { Ice wedges/Bead-shaped } \\
\text { forms }\end{array}$ \\
\hline 1.5 & Upper & 0.005 & 0 & 50 & 3 & Landslides/Dammed lakes \\
\hline 1.5 & Upper & 0.005 & 0 & 1700 & 94 & Landslides/Dammed lakes \\
\hline 3 & Middle & 0.0075 & 2800 & 0 & 104 & $\begin{array}{l}\text { Ice wedges/Bead-shaped } \\
\text { forms }\end{array}$ \\
\hline \multirow[t]{2}{*}{5} & Lower & 0.015 & 1185 & 0 & 22 & $\begin{array}{l}\text { Ice wedges/Bead-shaped } \\
\text { forms }\end{array}$ \\
\hline & Total & & 4190 & 1750 & 220 & \\
\hline
\end{tabular}

cycle. Beads reduce water runoff in the channel by three to four orders of magnitude (Table 9).

Cryogenic processes determine the particularities of the sediment transport through the channel. Cryogenic landsliding at the upper course expose surface deposits which are eroded into the channel. As long as the dammed lake exists, sediment load settles in these lakes, but after the drainage of the dammed lakes, the sediment is transported downstream to fill in the bead-shaped ponds of the middle course. In the lower course, as there are no bare surfaces produced by landsliding, the water discharge is much higher than in the upper course. Sediment load is reduced by middle-course beadshaped ponds, so water flow can produce both thermokarst and erosive work in the lower course. Bead-shaped ponds are filled in with the sediment and their depth reduces downstream as measured in the lower course of the test river (Table 9).

We distinguish valley slopes with temporary streams, and small river banks and channels in the upper, middle and lower course. Activity of the erosion and thermoerosion in temporary stream network on slopes of the river valleys is controlled by landslide process. Concave bare or sparsely vegetated landslide shear surfaces are concentrating water runoff into temporary channels, easier to erode. Hydrological processes depend on the position against the landslide headwall and on the depth of the shear surface cutting into the sur- rounding slopes. Temporary streams on landslide affected slopes are an important source of sediment runoff in the small rivers.

Cryogenic landsliding results in the active sediment washout from the exposed landslide shear surfaces into a channel, and the 'bead' forms, occurring on adjacent portions of the channel which are filled with these sediments. However, when landslide bodies still dam the channels, they interfere with sediment transport and thus promote longer existence of bead-shaped channels downstream.

The complexes of cryogenic and hydrologic processes, characteristic for upper, middle and lower stream courses in the small catchments are: (1) a landslide complex of the upper course with the subsidiary bottom thermoerosion and prevalence of accumulation above sediment evacuation; (2) thermokarst complex of the middle course with equilibrium of accumulation and sediment evacuation, and (3) thermoerosion complex of the lower course with subsidiary thermokarst, and prevalence of sediment evacuation above accumulation.

\section{Conclusion}

The comprehensive investigations at the Vaskiny Dachi research station within the last 25 years demonstrates that cryogenic landslides control the development of other processes, such as thermal 
erosion, river channel erosion and thermokarst. It also affects topography, vegetation, ground water, soils and their geochemistry. As a result, active layer depth and ground temperature, moisture and ice content in the active layer, depend indirectly on landsliding. The land surface and subsurface temperature in continuous permafrost areas is changing with air temperature and winter precipitation fluctuations, as well as the surface cover response to these fluctuations Landforms result from the interaction of cryogenic and hydrological processes. The long-term observations form the basis for prediction of future changes as well as improved understanding about land surface changes in similar subarctic environments. Future studies will be mainly devoted to the modeling of permafrost temperature and using remote-sensing data to monitor landform changes.

\section{ACKNOWLEDGEMENTS}

This summary was made possible through COLDYamal project funded by RFBR grant No. 13-05-91001-AНФ-a to the Earth Cryosphere Institute SB RAS. Authors are grateful to anonymous reviewers for useful comments and indebted to Hanna Salo from University of Turku for thoroughly editing the text.

\section{REFERENCES}

Ananieva GV 1984. Slope processes as indicators of cryogenic construction of permafrost on locations with massive ground ice distribution. In Melnikov ES (ed). Study and prediction of cryogenic physical-geological processes, 12-17. VSEGINGEO, Moscow (in Russian).

Ananieva GV 1997. Peculiarities of engineering-geological conditions of the northern part of designed railway Obskaya-Bovanenkovo. In Melnikov ES (ed). The results of fundamental research of the Earth cryosphere in Arctic and Subarctic, 173182. Nauka, Novosibirsk (in Russian).

Anisimova NP 1981. Cryohydrochemical peculiarities of the permafrost zone. Nauka, Novosibirsk (in Russian).

Dan'ko VK 1982. The regularities of the thermoerosion process development in the north of West Siberia. Candidate of science dissertation. PNIIIS, Moscow (in Russian).

Ermokhina KA 2009. Phyto-indication of exogenous processes in the tundras of Central Yamal. Candidate of science dissertation. Moscow University, Moscow (in Russian).

Gorlanova LA 2002. Methods of dendrochronologic dating of landslide events. In Konishchev VN,
Grechishchev SE, Leibman MO, Pavlov AV, Perlshtein GZ \& Khrustalev LN (eds). Extremal cryospheric phenomena: Fundamental and applied aspects, 148-149. Scientific Council on Earth Cryology RAS, Pushchino.

Gubarkov AA 2006. Hydrogenic dynamics on the watersheds of Central Yamal. In Geology and oilgas resources of the West-Siberian mega-basin. Materials of scientific-practical conference 2, 14-16. Vector, Tyumen (in Russian).

Gubarkov AA 2007. Dynamics of cryogenic and hydrologic processes in the small catchments of Central Yamal. In Oil and gas of West Siberia. Materials of All-Russia scientific-practical conference, 221-224. TSOGU, Tyumen (in Russian).

Gubarkov AA 2009. Interrelation of hydrologic and cryogenic processes in the basins of small rivers and on the Kara sea coast. Candidate of science dissertation. TSOGU, Tyumen (in Russian).

Gubarkov AA 2011a. Cryogenic processes in the small river basins of Central Yamal. In VN Kotlyakov, MY Moskalevsky (eds). Abstracts of the conference to develop a program of international polar decade, 33. Institute of Geography RAS, Sochi (in Russian).

Gubarkov AA 2011b. Exogenous geological processes in the zone of designed gas pipeline "Bovanenkovo-Ukhta" on Yamal Peninsula. Transactions of the high school. Oil and gas 4, 30-25. (in Russian).

Gubarkov AA \& Andreeva MV 2011. Cryogenic processes in the small-river catchments of Central Yamal. In The 4th conference of Russian geocryologists 4, 22-27. University Book, Moscow (in Russian).

Gubarkov AA \& Leibman MO 2007. Erosion processes on the share surfaces of cryogenic landslides: a case study at Vaskiny Dachi station. In Proceedings of the international conference Cryogenic resources of polar regions II, 136-138, Scientific Council on Earth Cryology RAS, Pushchino-Salekhard.

Gubarkov AA \& Leibman MO 2008a. Interrelation of cryogenic and hydrologic processes on small streams and catchments of Central Yamal. In Kane DL \& Hinkel KM (eds). Proceedings of the 9th international conference on permafrost 1, 563-569. University of Alaska, Fairbanks.

Gubarkov AA \& Leibman MO 2008b. Impact of cryogenic formations on the run-off types in the smallriver basins of Central Yamal (Polygon Vaskiny Dachi). In Cryogenic resources of polar and mountain regions. State and prospects of engineering geocryology. Proceedings of the international conference, 390-393. TSOGU, Tyumen.

Gubarkov AA \& Leibman MO 2010. Bead-shaped channel forms as an evidence of paragenesis of cryogenic and hydrological processes in the smallriver valleys of central Yamal 2010. Earth Cryosphere (Kriosfera Zemli) XIII: 1, 41-49. (in Russian).

Gubarkov A, Leibman M \& Andreeva M 2014. Cryogenic landslides in paragenetic complexes of slope and channel processes in the Central Yamal Peninsula In Shan W, Guo Y, Wang F, Marui H \& Strom A (eds). Landslides in cold regions in the 
context of climate change, environmental science and engineering, 291-308. Springer International Publishing, Switzerland.

Gubarkov AA, Leibman MO \& Khomutov AV 2012. Cryogenic processes in natural and technogenic conditions of Kharasavey gas field. Transactions of the high school. Oil and gas 3, 21-27. (in Russian). Gubarkov AA, Leibman MO, Korosteleva OV 2006. Hydrogenic dynamics on Central Yamal (polygon Vaskiny Dachi). In Theory and practice of estimating the state of the Earth Cryosphere and prediction of its change. Materials of the international conference I, 213-216. TSOGU, Tyumen.

Hantemirov RM \& Shiyatov SG 2002. A continuous multimillennial ring-width chronology in Yamal, northwestern Siberia. Holocene 12: 6, 717-726.

Hantemirov RM \& Shiyatov SG 2003. Yamal Peninsula multimillennial summer temperature reconstruction. IGBP PAGES/World Data Center for Paleoclimatology Data Contribution Series \# 2003-029. NOAA/NGDC Paleoclimatology Program. Boulder CO, USA.

Kaplina TN 1965. Cryogenic slope processes. Nauka, Moscow (in Russian).

Khomutov AV 2010. Relation of natural cryogenic processes with the dynamics of tundra landscapes, case study in subzone of typical tundra of the Kara region. Candidate of science dissertation. The Earth Cryosphere Institute SB RAS, Tyumen (in Russian).

Khomutov AV 2012. Assessment of landslide geohazards in typical tundra of Central Yamal. In Drozdov DS \& Romanovsky VE (eds). 10th international conference on permafrost 2. Translations of Russian contributions, 157-162. The Northern Publisher, Salekhard.

Khomutov AV \& Leibman MO 2010a. Landscape pattern and cryogenic landsliding hazard analysis on Yamal peninsula, Russia. In Mertes JR, Christiansen $\mathrm{HH}$ \& Etzelmüller B (eds). Thermal state of frozen ground in a changing climate during the IPY. Abstracts from the 3rd European Conference on Permafrost, 254. The University Centre, Svalbard.

Khomutov AV \& Leibman MO 2010b. Probability of landslide activation in the typical tundra of Central Yamal. In Kotlyakov VN \& Moskalevsky MY (eds). Abstracts of the Conference to develop a program of international polar decade, 63-64. Institute of Geography RAS, Sochi (in Russian).

Khomutov AV \& Leibman MO 2011. Estimation of landslide hazard in the typical tundra of Central Yamal. In Melnikov VP \& Bruchkov AV (eds). 4th conference of Russian geocryologists 2, 348-355. University Book Publisher, Moscow (in Russian).

Khomutov A \& Leibman M 2014. Assessment of landslide hazards in a typical tundra of Central Yamal In Shan W, Guo Y, Wang F, Marui H \& Strom A (eds). Landslides in cold regions in the context of climate change, Environmental science and engineering, 271-290. Springer International Publishing, Switzerland.
Khomutov AV, Leibman MO, Moskalenko NG \& Epstein HE 2010. Correlation between active layer depth and vegetation parameters at Vaskiny Dachi, Central Yamal, Russia. In Mertes JR, Christiansen $\mathrm{HH} \&$ Etzelmüller B (eds). Thermal state of frozen ground in a changing climate during the IPY. Abstracts from the 3rd European Conference on Permafrost, 227. The University Centre, Svalbard.

Kizyakov Al 2005a. Dynamics of the thermodenudation processes on the coast of Yugorsky Peninsula. Earth Cryosphere (Kriosfera Zemli) IX: 1, 63-67. (in Russian)

Kizyakov Al 2005b. Dynamics of thermodenudation processes in the regions with tabular ground ice distribution. Candidate of science dissertation. Moscow State University, Moscow (in Russian).

Kizyakov AI \& Ermakov SY 2001. Reconstruction of landslide rhythms as a result of study of composition, morphology and structure of landslide cirques. In Abstracts of presentations on the International conference "Conservation and transformation of substance and energy in the Earth Cryosphere", 123-124. POLTEX Publisher, Moscow.

Kizyakov AI, Leibman MO \& Perednya DD 2006. Destructive relief-forming processes at the coasts of the Arctic plains with tabular ground ice. Earth Cryosphere (Kriosfera Zemli) X: 2, 79-89. (in Russian).

Leibman MO 1994. Cryogenic landslides and their interaction with linear constructions on Yamal Peninsula, Russia. In Smith DW \& Sego DC (eds). Proceedings of the 7 th international cold regions engineering specialty conference, 865-869. Montreal, Quebec. Edmonton.

Leibman MO 1995. Preliminary results of cryogenic landslides study on Yamal Peninsula, Russia. Permafrost and Periglacial Processes 6: 3, 259-264. DOI: $10.1002 /$ ppp.3430060307.

Leibman MO 1997. Cryolithilogical peculiarities of the seasonally thawed layer on slopes in relation to the landslide process. Earth Cryosphere (Kriosfera Zemli) 1: 2, 50-55. (in Russian).

Leibman MO 1998. Active layer depth measurements in marine saline clayey deposits of Yamal Peninsula, Russia: Procedure and interpretation of results. In Lewkowizc AG \& Allard M (eds). Permafrost. Proceedings of the 7 th international conference, 635-639. Collection Nordicana. Centre d'Etudes Nordiques, Université Laval, Yellowknife.

Leibman MO 2001. Procedures and results of activelayer measurements in marine saline deposits of Central Yamal. Earth Cryosphere (Kriosfera Zemli) $\mathrm{V}:$ 3, 17-24. (in Russian).

Leibman MO 2004a. Mechanisms and stages of slope cryogenic process formation in the western sector of Russian Arctic. Novikov IS (ed). Relief forming processes: Theory, practice, research methods. Materials of XXVIII Plenum of Geomorphic Commission, 160-162. IG SB RAS, Novosibirsk (in Russian).

Leibman MO 2004b. Mechanisms of formation of cryogenic translational landslides and conditions for their indication by high willow shrubs on Central Yamal. Transactions of the Moscow Center of 
Russian Geographical Society. Biogeography 12, 89-94. RASHN, Moscow (in Russian).

Leibman MO 2005. Cryogenic slope processes and their geoecologic consequences under the tabular ground ice distribution. Doctor of science dissertation. Earth Cryosphere Institute SB RAS, Tyumen (in Russian).

Leibman MO \& Egorov IP 1996. Climatic and environmental controls of cryogenic landslides, Yamal, Russia. In Senneset K (ed). Landslides, 1941-1946. Balkema Publishers, Rotterdam.

Leibman MO \& Kizyakov Al 2007. Cryogenic landslides of the Yamal and Yugorsky Peninsulas. Earth Cryosphere Institute SB RAS, Moscow (in Russian).

Leibman MO \& Streletskaya ID 1996. Migration of chemical elements and ions in the active layer and upper part of permafrost in connection with thermodenudation processes on Yamal Peninsula. In Melnikov VP \& Bruchkov AV (eds). Proceedings of the first conference of Russian geocryologists 2, 390398. Faculty of Geology MSU, Moscow (in Russian).

Leibman MO \& Streletskaya ID 1997. Land-slide induced changes in the chemical composition of active layer soils and surface-water run-off, Yamal Peninsula, Russia. In Iskandar IK, Wright EA, Radke JK, Sharratt BS, Groenevelt PH \& Hinzman LD (eds.) Proceedings of the international symposium on physics, chemistry, and ecology of seasonally frozen soils, 120-126. Fairbanks, Alaska. CRREL Special Report 97-10. CRREL, Hanover.

Leibman M, Khomutov A \& Kizyakov A 2014. Cryogenic landslides in the West-Siberian plain of Russia: Classification, mechanisms, and landforms. In Shan W, Guo Y, Wang F, Marui H \& Strom A (eds). Landslides in cold regions in the context of climate change, environmental science and engineering, 143-162. Springer International Publishing, Switzerland.

Leibman MO, Rivkin FM \& Saveliev VS 1993a. Hydrogeological aspects of cryogenic slides on the Yamal peninsula. In Cheng G (ed). Permafrost. Proceedings of the 6th international conference 1, 380-382. South China University of Technology Press, Beijing.

Leibman MO, Rivkin FM \& Streletskaya ID 1993b. Chemical and physical features of the active layer as related to landslides on Yamal Peninsula. In Joint Russian-American Seminar on Cryopedology and Global Change. Post-Seminar Proceedings, 257262. Russian Academy of Sciences, Pushchino.

Leibman MO, Streletskaya ID \& Konyakhin MA 1997. Assessment of surface dynamics at Bovanenkovo gas field (Central Yamal Peninsula) during the period 1949 to 1990. Geomorphology 2: 45-48. (in Russian).

Leibman MO, Archegova IB, Gorlanova LA \& Kizyakov Al 2000. Stages of cryogenic landslides on Yugorsky and Yamal Peninsulas. Earth Cryosphere (Kriosfera Zemli) IV: 4, 67-75 (in Russian).

Leibman MO, Kizyakov AI, Sulerzhitsky LD \& Zaretskaya NE 2003. Dynamics of the landslide slopes and mechanism of their development on Yamal peninsula, Russia. In Phillips M, Springman SM \&
Arenson LU (eds). Permafrost. Proceedings of the 8th international conference, 651-656. A.A.Balkema Publishers, Lisse.

Leibman MO, Lakhtina OV, Miklyaev SM \& Titova IR 1991. Pattern of relief-forming cryogenic process distribution at Western Yamal Peninsula. In Melnikov PI \& Popov Al (eds). Denudation in cryolithozone, 92-99. Nauka, Moscow (in Russian).

Leibman MO, Epstein HE, Khomutov AV, Moskalenko NG \& Walker DA 2008. Relation of active layer depth to vegetation on the Central Yamal Peninsula, Russia. In Kane DL \& Hinkel KM (eds). Extended abstracts of the 9th international conference on permafrost, 177-178. University of Alaska, Fairbanks.

Leibman MO, Khomutov AV, Orekhov PT, Gameev IA, Gubarkov AA \& Walker DA 2010. Spatial distribution of the active layer depth along the Yamal transect. In Mertes JR, Christiansen HH \& Etzelmüller B (eds). Thermal state of frozen ground in a changing climate during the IPY. Abstracts from the 3rd European conference on permafrost, 226. The University Centre, Svalbard.

Leibman MO, Khomutov AV, Orekhov PT, Khitun OV, Epstein H, Frost G \& Walker DA 2012. Gradient of seasonal thaw depth along the Yamal transect. In Drozdov DS \& Romanovsky VE (eds). Proceedings of the 10th international conference on permafrost 2. Translations of Russian Contributions, 237-242. The Northern Publisher, Salekhard.

Leibman MO, Moskalenko NG, Orekhov PT, Khomutov AV, Gameev IA, Khitun OV, Walker DA \& Epstein HE 2011. Interrelation of cryogenic and biotic components of geosystems in cryolithozone of West Siberia on the Transect "Yamal". In Kotlyakov VM (ed). Polar cryosphere of water and land, 171-192. Paulsen Publisher, Moscow (in Russian).

Lewkowicz AG 1988. Slope processes. In Clark MJ (ed). Advances in periglacial geomorphology, 325-368. Wiley, New York.

Lewkowicz AG 1990. Morphology, frequency and magnitude of active-layer detachment slides, Fosheim Peninsula, Ellesmere Island, N.W.T. In Burgess MM, Harry DG \& Sego DC (eds). Proceedings of the 5th Canadian permafrost conference. Collection Nordicana 54, 111-118. Laval University, Quebec. Melnikov ES, Leibman MO, Moskalenko NG \& Vasiliev AA 2004. Active-layer monitoring in the cryolithozone of West Siberia. Polar Geography 28: 4, 267-285. DOI:10.1080/789610206.

Naletova NS 1996. Mass transfer and cryogenic texture and structure formation in freezing saline soils. Candidate of science thesis. Faculty of Geology. Moscow University, Moscow.

Osadchaya GG 1987. Influence of snow and vegetation covers on cryogenic processes. In Cryogenic processes, 170-182. Moscow University Press, Moscow (in Russian).

Poznanin VL \& Baranov AV 1999. Cryogenic slope processes. In AY Sidorchuk, AV Baranov (eds). Erosion processes at Central Yamal, 119-132. 
RNII of Culture and Nature Inheritance, St-Petersburg (in Russian).

Rebristaya OV, Khitun OV, Chernyadieva IV \& Leibman MO 1995. Dynamics of vegetation on cryogenic landslides in the central Yamal Peninsula. Botanical Journal 80: 4, 31-48. (in Russian).

Romanenko FA 1997. Formation of the lake basins on Siberian Arctic plains. Candidate of science dissertation. Moscow University Press, Moscow (in Russian).

Shiyatov SG \& Gorlanova LA 1986. Pathologic structures in the timber of Siberian larch. In Botanical research in the Urals (information materials), 71. Institute of Plant and Animal Ecology UB AS USSR, Sverdlovsk (in Russian).

Shur YuL 1988. Upper horizon of permafrost layers and thermokarst. Nauka Publisher, Novosibirsk (in Russian).

Sidorchuk AY 1999. The sediment balance on ravine catchments. In Sidorchuk AY \& Baranov AV (eds). Erosion processes at Central Yamal, 242-252. RNII of Culture and Nature Inheritance, Saint-Petersburg (in Russian).

Sidorchuk AY 2000. Anthropogenic ravine erosion and thermoerosion in the western part of Central Yamal. Geomorphology 3, 95-103 (in Russian).

Streletskii DA, Streletskaya ID, Rogov VV \& Leibman MO 2003. Redistribution of ions within the active layer and upper permafrost, Yamal, Russia. In Phillips M, Springman SM \& Arenson LU (eds). Permafrost. Proceedings of the 8th international conference 2, 1117-1122. A.A.Balkema Publishers, Lisse.

Tentyukov MP 1998. Geochemistry of landscapes of Central Yamal. Ural Branch RAS, Ekaterinburg (in Russian).

Ukraintseva NG \& Leibman MO 2007. The effect of cryogenic landslides (active-layer detachments) on fertility of tundra soils on Yamal peninsula, Russia. In Schaefer VR, Schuster RL \& Turner AK (eds). Landslides/slope instability. AEG Special Publication; v. 23. Conference presentations from the 1st North American landslide conference, 1605-1615. The Association of Environmental and Engineering Geologists, Vail, Colorado.

Ukraintseva NG, Leibman MO \& Sreletskaya ID 2000. Peculiarities of landslide process in saline frozen deposits of Central Yamal, Russia. In Bromhead $\mathrm{E}$ (ed). Landslides in research, theory and practice: Proceedings of the 8th international symposium on landslides 3, 1495-1500. Cardiff UK. Thomas Telford, London.

Ukraintseva N, Leibman M, Streletskaya I \& Mikhaylova T 2014. Geochemistry of plant-soil-permafrost system on landslide-affected slopes, Yamal, Russia as an indicator of landslide age In Shan W, Guo Y, Wang F, Marui H \& Strom A (eds). Landslides in cold regions in the context of climate change, environmental science and engineering, 107-132. Springer International Publishing, Switzerland.

Ukraintseva NG, Streletskaya ID, Ermokhina KA \& Yermakov SY 2003. Geochemical properties of plant-soil-permafrost system at landslide slopes, Yamal, Russia. In Phillips M, Springman SM \& Arenson LU (eds). Permafrost. Proceedings of the 8th international conference 2, 1149-1154. A.A.Balkema Publishers, Lisse.

Ukraintseva NG, Leibman MO, Streletskaya ID, Yermokhina KA \& Smetanin NN 2002. Monitoring of the landslide on saline frozen deposits in typical tundra subzone (Yamal, Bovanenkovo Gas-field area). In Proceedings of the international conference ecology of northern territories of Russia. Problems, prediction of situation, ways of development, solutions 2: 1, 832-837. Institute of Ecology of the North UrB RAS, Arkhangelsk (in Russian).

Vasiliev AA, Leibman MO \& Moskalenko NG 2008. Active layer monitoring in West Siberia under the CALM II Program. In Kane DL \& Hinkel KM (eds). Proceedings of the 9th international conference on Permafrost 2, 1815-1820. University of Alaska, Fairbanks.

Voskresenskiy KS 1999. Landslides-flows and thermokarst. In Sidorchuk AY \& Baranov AV (eds). Erosion processes at Central Yamal, 133-139. RNII of Culture and Nature Inheritance, St-Petersburg (in Russian).

Walker DA, Jia GJ, Epstein HE, Raynolds MK, Chapin FS III, Copass C, Hinzman LD, Knudson JA, Maier HA, Michaelson GJ, Nelson F, Ping CL, Romanovsky VE \& Shiklomanov N 2003. Vegetation-soilthaw-depth relationships along a low-Arctic bioclimatic gradient, Alaska: Synthesis of information from the ATLAS studies. Permafrost and Periglacial Processes 14: 2, 103-123. DOI: 10.1002/ppp.452.

Yershov ED 1998. General geocryology. Cambridge University Press, West Nyack, NY. 